SílVIO COUTO RAMOS

Comparação de diferentes indicadores com método de coleta total para determinação da digestibilidade aparente de diferentes dietas para eqüinos

Pirassununga

2003 


\title{
Comparação de diferentes indicadores com método de coleta total para determinação da digestibilidade aparente de diferentes dietas para eqüinos
}

\begin{abstract}
Dissertação apresentada ao programa de Pós-graduação em Nutrição Animal da Faculdade de Medicina Veterinária e Zootecnia da Universidade de São Paulo para obtenção do título de Mestre em Medicina Veterinária
\end{abstract}

Departamento:

Nutrição e Produção Animal

Área de concentração:

Nutrição Animal

Orientador:

Prof. Dr. Alexandre Augusto de Oliveira Gobesso 


\section{DADOS INTERNACIONAIS DE CATALOGAÇÃO-NA-PUBLICAÇÃO}

(Biblioteca da Faculdade de Medicina Veterinária e Zootecnia da Universidade de São Paulo)

T.1335

FMVZ

\section{Ramos, Silvio Couto}

Comparação de diferentes indicadores com método de coleta total para determinação de digestibilidade aparente de diferentes dietas para eqüinos / Silvio Couto Ramos. - Pirassununga : S. C. Ramos, 2003. $69 \mathrm{f}$ : : il.

Dissertação (mestrado) - Universidade de São Paulo. Faculdade de Medicina Veterinária e Zootecnia. Departamento de Nutrição e Produção Animal, 2003.

Programa de Pós-graduação: Nutrição Animal.

Área de concentração: Nutrição Animal.

Orientador: Prof. Dr. Alexandre Augusto de Oliveira Gobesso.

1. Equainos. 2. Digestibilidade. 3. Lignina. 4.Óxido crômico. 5. Milho. I. Título. 


\section{FOLHA DE AVALIAÇÃO}

Nome do autor: RAMOS, Sílvio Couto

Título: Comparação de diferentes indicadores com método de coleta total para determinação da digestibilidade aparente de diferentes dietas para eqüinos

Dissertação apresentada ao programa de Pós-graduação em Nutrição Animal da Faculdade de Medicina Veterinária da Universidade de São Paulo para obtenção do título de Mestre em Medicina Veterinária.

Data:

1

Prof. Dr.

Assinatura:

Prof. Dr.

Assinatura:

Prof. Dr.

Assinatura:
Instituição:

Julgamento:

Instituição:

Julgamento:

Instituição:

Julgamento: 
Até aqui nos ajudou o senhor...

Ebenezer 


\section{AGRADECIMENTOS}

Ao Prof. Dr. Alexandre Augusto de Oliveira Gobesso, pela oportunidade de orientação e apoio concedido ao longo desse experimento.

Aos professores do Departamento de Nutrição e Produção Animal da Faculdade de Medicina Veterinária e Zootecnia da Universidade de São Paulo pelos valiosos ensinamentos transmitidos durante a realização deste curso.

A minha esposa Tânia pelo estimulo e dedicação constantes nos momentos mais difíceis.

A meus pais Vitorino e Zoréa, exemplos de trabalho e perseverança.

A meus filhos Yasmine e Tharik pela compreensão de minha ausência.

A Laércio e Fernanda Casalecchi por permitir a realização desse experimento em sua propriedade.

Aos amigos Celso Lorenzo, Mariano Etchutchury e Ari de Castro pelas sugestões que muito me ajudaram nos momentos de dúvida.

Ao professor Romualdo Fukushima, pela cessão do material utilizado no experimento e ao professor César Gonçalves de Lima, pela orientação dada a parte estatística deste projeto.

A meus colegas na FMVZ, pelo companheirismo e bom humor.

A funcionários do Departamento de Nutrição e Produção Animal pelo apoio e ajuda fundamental para execução desse trabalho.

A Fernando Costa, homem à frente de seu tempo, responsável pela criação da UFRRJ e pela implementação do Campus de Pirassununga da Universidade de São Paulo escola as quais sou grato pela formação acadêmica.

A DEUS por ter me dado a oportunidade de recomeçar. 


\section{RESUMO}

RAMOS, S. C. Comparação de diferentes indicadores com método de coleta total para determinação da digestibilidade aparente de diferentes dietas para eqüinos. [Different markers comparison with total collection method to determine the apparent digestibility in different equine diets]. 69 p. Dissertação (Mestrado em Nutrição Animal) Faculdade de Medicina Veterinária e Zootecnia, Universidade de São Paulo, Pirassununga, 2003.

Foram utilizadas quatro eqüinos fêmeas, adultas, sem raça definida com peso médio de $450 \pm 51.15 \mathrm{~kg}$. As foram compostas de partes iguais de feno da gramínea Tifton 85 (Cynodon sp) e concentrado contendo milho submetido a quatro processamentos diferentes (moído, laminado, floculado, extrusado). O experimento teve duração de 11 dias sendo oito de adaptação a dieta e 3 dias de coleta. O delineamento experimental utilizado foi quadrado latino $4 \times 4$ (tratamento $\mathrm{x}$ animal). $\mathrm{O}$ objetivo deste trabalho foi de comparar o indicador externo oxido crômico e os indicadores internos, lignina em detergente ácido (LDA), cinza insolúvel em detergente ácido (CIDA) com o método de coleta total (CT) para determinação da digestibilidade aparente da matéria orgânica (CDMO) A ponderação dos CDMO pelos indicadores foi efetuada através de um modelo o qual considerava a diferença entre o CDMO pelo indicador e pela CT aqui chamado de viés. A variância das respostas dos quatro indicadores são iguais, tendo assim a mesma precisão para estimar os CDMO. As médias das diferenças entre CT e os indicadores são diferentes de zero para cada indicador. 
Foi observada maior acurácia para a metodologia utilizando a lignina, em comparação aos demais indicadores testados $(P<0,05)$, porem esta ainda se manteve distante dos resultados obtidos através da coleta total. O óxido crômico subestimou os coeficientes de digestibilidade, enquanto que a CIDA superestimou os valores. Entretanto, quanto à precisão, o indicador óxido crômico foi constatado ser o mais preciso em relação aos demais indicadores estudados $(P<0,05)$.

Palavras-chaves: Eqüinos. Digestibilidade.Lignina.Óxido Crômico.Milho 
RAMOS, S. C. Different markers comparison with total collection method to determine the apparent digestibility in different equine diets. [Comparação de diferentes indicadores com método de coleta total para determinação da digestibilidade aparente de diferentes dietas para eqüinos] 69 p. Dissertação (Mestrado em Nutrição Animal) Faculdade de Medicina Veterinária e Zootecnia, Universidade de São Paulo, Pirassununga, 2003.

Four adult mares, with no defined breed and an average weight of $450 \pm$ $51.15 \mathrm{kgwere}$ used. The diets were composed of equal parts of Tifton 85 hay (Cynodon sp) and concentrate of corn submitted to four different processes (grinded, laminated, flocculated and extruded). The experiment lasted 11days, being 8 for diet adaptation and 3 for collection. The experimental design used was a Latin square $4 \times 4$ (treatment $x$ animal). The objective of this experiment was to compare the external marker oxide chromic and the internal markers acid lignin detergent (ADL), Acid Detergent Insoluble Ash (ADIA) with the total collection method (TC) to determine the apparent digestibility of Organic Matter (OM). The consideration of OMDC by the by the markers was done through a model that took into account the difference between OMDC by the marker and the TC here called bias. The answer variation in the four markers is the same, this way demonstrating the same accuracy to estimate the OMDC. The average differences between TC and the markers are different from zero to each marker. It was observed a grater accuracy in the methodology using lignin, compared to the other markers tested $(p<0,05)$. However, this one was still for from the results obtained through the total collection. The oxide chromic underestimated the digestibility coefficients, while ADIA overestimated the 
values. The marker oxide chromic was reported as being the most precise in relation to the others markers studied.

Key words: Equine. Digestibility. Lignin, Oxide Chromic. Corn 


\section{LISTA DE TABELAS}

Tabela 1 - Formulação do concentrado experimental (\%). Pirassununga 2003

Tabela 2 - Valores médios da composição bromatológica dos ingredientes dos quatro suplementos concentrados (100\% da MS). Pirassununga 2003

Tabela 3 - Composição bromatológica do feno da gramínea Tifton 85 (Cynodon sp) e da fração concentrado com as quatro formas de processamento do milho (100\% da MS). Pirassununga 2003-----

Tabela 4 - Condições de temperatura, permanência no sistema, umidade, pressão e tipo de rolo necessário para as diferentes formas de processamento de grãos de milho (inteiro, laminados, triturados, moídos e expandidos) oferecidos aos animais. Pirassununga 2003

Tabela 5 - Media de peso vivo $(\mathrm{kg})$, consumo ( $\mathrm{kg} \mathrm{MS} / \mathrm{dia})$ e proporção de consumo de matéria seca por peso vivo de dietas compostas de feno da gramínea Tifton 85 (Cynodon sp) e do concentrado com as quatro formas de processamento do milho (100\% da MS). Pirassununga 2003

Tabela 6 - Coeficientes médios e erro padrão da digestibilidade aparente da matéria orgânica (CDMO) obtidos através da coleta total (CT) e dos indicadores Cinza Insolúvel em Detergente Ácido (CIDA), Lignina (LIG) e Óxido Crômico $\left(\mathrm{Cr}_{2} \mathrm{O}_{3}\right)$ de dietas compostas de feno da gramínea Tifton 85 (Cynodon sp) e concentrado com as quatro formas de processamento do milho (100\% da MS). Pirassununga 2003 
Tabela 7 - Conteúdo de indicadores internos no feno da gramínea Tifton 85 (Cynodon sp) e no concentrado contendo milho submetido a quatro processamentos diferentes (moído, laminado, floculado, extrusado). Pirassununga 2003

Tabela 8 - Conteúdo de indicadores nas dietas contendo feno da gramínea Tifton 85 (Cynodon sp) e concentrado contendo milho submetido a quatro processamentos diferentes triturado (TRIT), laminado (LAM), floculado (FLOC) e extrusado (EXTR). Pirassununga 2003

Tabela 9 - Valores de acurácia e precisão para os indicadores Cinza Insolúvel em Detergente Ácido (CIDA), Lignina (LIG) e Óxido Crômico $\left(\mathrm{Cr}_{2} \mathrm{O}_{3}\right)$. Pirassununga 2003

Tabela 10 - Eficiência de recuperação dos indicadores $\mathrm{Cr}_{2} \mathrm{O}_{3}$, CIDA e Lignina percentagem(\%) média de recuperação do Óxido Crômico, CIDA, LDA. Pirassununga 2003 


\section{LISTA DE ABREVIATURAS}

\begin{tabular}{|c|c|}
\hline AGV & Ácidos graxos voláteis \\
\hline $\mathrm{Ca}$ & Cálcio \\
\hline CDAN & Coeficiente digestibilidade aparente dos nutrientes \\
\hline CDMO & Coeficientes de digestibilidade aparente da matéria orgânica \\
\hline CIDA & Cinza Insolúvel em Detergente Ácido \\
\hline $\mathrm{Cr}_{2} \mathrm{O}_{3}$ & Óxido Crômico \\
\hline CT & Coleta total \\
\hline CV & Coeficiente de Variação \\
\hline EE & Extrato etéreo \\
\hline ERI & Eficiência de Recuperação do Indicador \\
\hline EXTR & Extrusado \\
\hline FB & Fibra Bruta \\
\hline FDA & Fibra Solúvel em Detergente Ácido \\
\hline FDN & Fibra Solúvel em Detergente Neutro \\
\hline FLOC & Floculado \\
\hline $\mathrm{IC} \mathrm{g}$ & Presença do indicador no alimento consumido em gramas \\
\hline IF $g$ & Presença do indicador nas fezes em gramas \\
\hline $\mathrm{Kg}$ & Quilogramas \\
\hline $\mathrm{Kgf} / \mathrm{cm} 2$ & Quilograma de força por centímetro quadrado \\
\hline LAMI & Laminado \\
\hline Lbs/in2 & Libras por polegada quadrada \\
\hline LDA & Lignina em detergente ácido \\
\hline
\end{tabular}




$\begin{array}{ll}\text { Min } & \text { Minuto } \\ \text { MM } & \text { Matéria Mineral } \\ \mathrm{mm}^{2} & \text { Milímetro } \\ \text { MO } & \text { Milímetro quadrado } \\ \text { MS } & \text { Matéria Orgânica } \\ \text { ND } & \text { Natéria Seca determinado } \\ \text { NRC } & \text { NATIONAL RESEACH COUNCIL } \\ \text { P } & \text { Fósforo } \\ \text { PB } & \text { Proteína Bruta } \\ \text { PV } & \text { Peso Vivo } \\ \text { QE g } & \text { Quantidade excretada do nutriente em gramas nas fezes. } \\ \text { QI g } & \text { Quantidade ingerida de um nutriente em gramas } \\ \text { TRAT } & \text { Tratamento } \\ \text { TRIT } & \text { Triturado }\end{array}$




\section{LISTA DE SÍMBOLOS}

$\begin{array}{ll}{ }^{\%} & \text { Porcentagem } \\ { }^{\circ} \mathrm{C} & \text { Graus Celsius } \\ = & \text { Somatório } \\ > & \text { Igual } \\ < & \text { Maior } \\ + & \text { Menor } \\ & \text { Mais }\end{array}$




\section{SUMÁRIO}

1 INTRODUÇÃO - - 16

2 REVISÃO DE BBIBLIOGRÁFICA 18

2.1 Considerações sobre o trato gastrintestinal dos eqüinos -

2.2 Efeitos do processamento na digestão dos alimentos ------------------- 22

2.3 Digestibilidade dos nutrientes--------

2.4 Métodos empregados para determinação de digestibilidade aparente 27

3 MATERIAL E MÉTODOS--.--.-- 35

3.1 Local-- 35

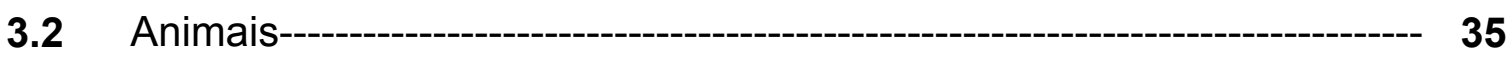

3.3 Clima-- 36

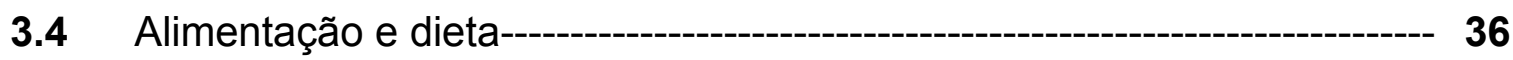

3.5 Processamento físico do milho-- 39

3.6 Metodologia de coleta e processamento de amostras- 40

3.7 Cálculo dos coeficientes de digestibilidade aparente----------------------- 42

3.8 Delineamento experimental --_- 46

4 RESULTADOS E DISCUSSÃO- 48

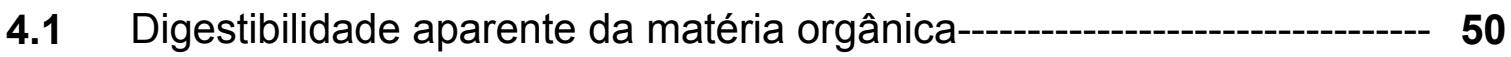

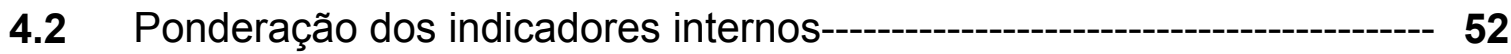

5 CONCLUSÕES-- 62

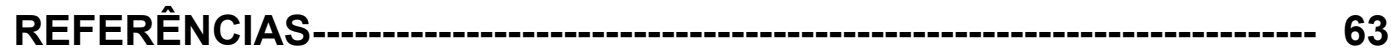




\section{INTRODUÇÃO}

A determinação da digestibilidade é conhecidamente o passo inicial para a avaliação da importância nutritiva de um alimento. $O$ conhecimento das peculiaridades fisiológicas inerentes a espécie eqüina conjuntamente com a avaliação da digestibilidade dos alimentos, são fundamentais para a evolução das pesquisas visando à criação de modelos nutricionais consistentes para essa espécie animal.

Ensaios de digestibilidade com eqüinos, através da coleta total de fezes, auxiliam a determinação da digestibilidade aparente total, ou seja, dão uma idéia de como se comportam os nutrientes ao longo de todo o trato gastrintestinal.

Esta técnica possui o inconveniente de restringir o número de animais experimentais à disponibilidade de infra-estrutura adequada, além de exigir mão-deobra qualificada. Outro fator negativo consiste em que durante o período experimental os animais ficam confinados em condições desfavoráveis a manutenção da espécie eqüina, levando a irregularidades fisiológicas com influencia negativa sobre o processo digestivo (NASCIMENTO, 2001).

Alternativamente ao método da coleta direta, tem sido proposto o método dos indicadores, ou indireto, que é fundamentado no emprego de uma substancia índice ou indicadora que, ao ser ingerida na dieta, deve ser totalmente recuperada nas fezes (SILVA; CAMPOS; CONRAD, 1968).

Muito se tem discutido sobre esse assunto, mas os pesquisadores ainda não conseguiram encontraram uma substância com características de indicador perfeito ou determinar um componente químico que se assemelhe mais com as 
características almejadas. Segundo Merchen (1993), nenhuma das substâncias utilizadas como indicadores preenchem todas essas características, mas várias são suficientemente adequadas para fornecer dados significativos. Por esta razão, a procura de indicadores ideais constitui um dos assuntos de grande importância na pesquisa de técnicas que facilitem estudos de nutrição animal. Nos últimos anos tem sido proposto o uso de várias substâncias ou novos métodos de análises que superariam algumas das limitações anteriores (PIAGGIO; PRATES; PIRES, 1991).

Alguns estudos têm sido conduzidos com o indicador externo óxido crômico $\left(\mathrm{Cr}_{2} \mathrm{O}_{3}\right)$ e com os indicadores internos, Cinza Insolúvel em Detergente Ácido (CIDA) e lignina em detergente ácido (LDA) na espécie eqüina, porém os resultados encontrados são muito controversos, necessitando ainda de maiores estudos.

O objetivo desta pesquisa foi comparar os valores de digestibilidade dos nutrientes de uma dieta composta por feno de Tifton 85 (Cynodon sp) e de concentrado composto por milho com diferentes formas de processamento (triturado, laminado, floculado e extrusado), farelo de soja, farelo de trigo e núcleo mineral obtidos através dos indicadores internos, Cinza Insolúvel em Detergente Ácido (CIDA), Lignina em Detergente Ácido (LDA) e do indicador externo óxido crômico, com aqueles obtidos pelo método de coleta total. 


\section{REVISÃO BIBLIOGRÁFICA}

O sistema digestivo dos eqüinos é o resultado das alterações dietéticas e mudanças nos hábitos alimentares ao longo de sua evolução, sendo adaptado para uma dieta compostas por grande número de forragens as quais podem variar nutricionalmente de acordo com as estações do ano (RALSTON, 1986).

Hintz (1983) relatou que o conhecimento da fisiologia da digestão dos eqüinos é essencial para práticas nutricionais consistentes, fazendo-se necessário conhecer não somente como o aparelho digestivo funciona, mas o quão eficiente pode vir a ser.

\subsection{Considerações sobre o trato gastrintestinal dos eqüinos}

Os eqüinos são classificados, segundo a anatomia do seu trato digestivo, como sendo herbívoros não ruminantes, mais especificamente podem ser considerados como herbívoros com ceco funcional, apresentando algumas vantagens sobre os estritamente não ruminantes e os ruminantes. Tais características anatômicas e fisiológicas permitem que os eqüinos possam absorver os carboidratos contidos nos concentrados energéticos antes do ataque da microflora intestinal.

O processo digestivo começa com a apreensão dos alimentos, pelos lábios e a língua sendo também utilizados os dentes incisivos na ingestão de substâncias 
mais firmes como tubérculos e ramos. Na boca, eqüinos com dentição funcional e intacta, esmagam e moem os alimentos, liberando proteínas e carboidratos que podem ser prontamente digeridos no estomago e intestino delgado (MEYER, 1995).

A mastigação é acompanhada por uma produção abundante de saliva, que possibilita a deglutição, umedecendo o alimento com quantidades de minerais e bicarbonato que servem para neutralizar os ácidos formados na porção inicial do estômago Meyer (1995), porém a saliva contém uma concentração muito baixa de amilase, praticamente sem tempo de atuar resultando em uma ação pré-gástrica insignificante (TISSERAND, 1983).

No esôfago o alimento é forçado para baixo através de ondas peristálticas ou através de contrações da musculatura. A deglutição no cavalo é feita de maneira irreversível em razão do desenvolvimento do véu palatino, que impede o retorno do bolo alimentar do esôfago para a boca e também impede a expulsão pelas vias nasais (TISSERAND, 1983).

O estômago dos eqüinos tem capacidade para 15 a 20 litros, ajustado para uma recepção contínua de pequenas quantidades de alimento. O estômago se preenche em camadas na região do saco cego aglandular e na região glandular fúndica, sendo posteriormente conduzido ao terço final onde será liquefeito. Os processos digestivos no estomago são concretizados por uma atividade simultânea das enzimas alimentares, microorganismos e do suco gástrico (MEYER, 1995).

Frape (1992) cita que o tempo de permanência dos alimentos no estômago varia de 2 a 3 horas, porém Konhke (1992) considera um tempo mínimo de retenção de 20 minutos, limitando assim a ação de secreções gástricas. Essa velocidade de trânsito, associada ao pH ácido, restringe a ação da população microbiana na fermentação de açúcares e amido. 
A mucosa duodenal possui glândulas que secretam suco entérico e grande quantidade de muco, suas inúmeras vilosidades revestidas de células epiteliais cilíndricas com microvilosidades aumentam a superfície de absorção dos alimentos (MEYER 1995).

Wolter (1975) cita que a parede do intestino delgado é muito musculosa, rígida e ricamente enervada, propiciando a geração de fortes ondas de contração, facilitando assim a progressão da digesta associada a sua grande fluidez resultante do sinergismo das secreções salivar, gástrica, pancreática, biliar e entérica. A digestão, no intestino delgado dos eqüinos é intensa e predominantemente enzimática. Os principais nutrientes digeridos são, proteína bruta (PB), extrato etéreo (EE), amido e carboidratos, semelhante à digestão dos monogástricos (FRAPE 1992; HINTZ 1979; KOHNKE 1992; WOLTER, 1975).

O intestino grosso do cavalo compreende seções volumosas, bem articuladas e compartimentalizadas. A atividade do ceco e do cólon depende principalmente do tipo e da quantidade de substâncias nutritivas provenientes do intestino delgado, da velocidade de trânsito da ingesta e da capacidade de tamponamento no lúmen. 0 número de microorganismos no conteúdo do intestino grosso de eqüinos é semelhante ao encontrado no rúmen e retículo dos ruminantes Meyer (1995). Kern et al. (1974), verificaram que no ceco e no cólon proximal a população microbiana é da ordem de 5 a $7 \times 10^{\mathrm{g}}$ microorganismos por grama de conteúdo digestivo, diminuindo pela metade no cólon terminal.

Koller (1978) utilizando pôneis fistulados no ceco e bovinos fistulados no rúmen, concluíram que as bactérias do rúmen digerem matéria seca e parede celular vegetal mais eficientemente do que as bactérias cecais, mesmo quando expostas a semelhantes intervalos de tempo. Frape (1986) também cita a reduzida capacidade 
dos eqüinos em digerir fibras em relação a ruminantes domésticos, sendo assim, gramíneas antes do florescimento por possuírem uma proporção maior de folhas seriam ideais na dieta de eqüinos.

Devido à digestão e absorção de carboidratos solúveis e da proteína ocorrerem antes do intestino grosso, pouco substrato além de material fibroso atinge o ceco do eqüinos, podendo prejudicar a população de microrganismos, diminuindo assim o aproveitamento dos carboidratos estruturais (UDEN; COLLUCCI; van SOEST, 1982).

Arnold et al. (1983) comparando as diferentes contribuições do intestino delgado e grosso na digestão do amido em pôneis alimentados com grãos de milho, aveia ou sorgo, recebendo $50 \%$ de feno de Coastal Bermuda, concluíram que quanto menor o consumo de amido, independente da fonte, maior será a contribuição do intestino delgado na digestão deste.

Segundo Gray (1992), a estrutura do amido, composta por amilose mais amilopectina, é clivada na cavidade duodenal pela enzima alfa-amilase secretada pelo pâncreas, originando di e trissacarídeos e alfa-dextrinas, que posteriormente, sofrem hidrólise, pela ação complementar de três enzimas presentes na borda em escova da superfície intestinal. O monossacarídeo gerado como produto final, a glicose, é então co-transportado para o interior dos enterócitos através do íon sódio, por uma proteína transportadora específica (75-kDA) presente na superfície da borda em escova, numa taxa limitante de assimilação de amido. Devido a esta digestão seqüencial luminal e membranosa, seguida pelo transporte de glicose, o amido é assimilado de maneira muito eficiente em animais não ruminantes.

O tempo de permanência do alimento nos diversos segmentos do trato gastrintestinal depende de múltiplos fatores, tais como individualidade, granulometria 
das partículas, digestibilidade e pureza dos alimentos Meyer (1995), além da freqüência da alimentação, do tipo de exercícios, dos ingredientes da dieta, da temperatura ambiente e o teor de fibra da ração (WARNER, 1981).

\subsection{Efeitos do processamento na digestão dos alimentos}

O intuito do processamento de alimentos é mudar forma física - química dos ingredientes resultando aumento na disponibilidade dos nutrientes para os animais e ao mesmo tempo preservar a qualidade dos nutrientes na matéria prima por tempo mais longo possível. O National Reseach Council (NRC) em sua edição de 1988 aconselha o processamento de alimentos fornecidos a eqüinos como forma de elevar a digestibilidade dos alimentos.

O processamento físico dos grãos consiste na quebra, moagem, trituração ou laminação de grãos secos, a desvantagem dessa forma de processamento parece ser a redução do período de armazenamento pela exposição do endosperma de amido e os lipídios das sementes à oxidação. As modificações físicos-químicas envolvem a aplicação de calor, água e pressão (floculação, laminação a vapor e extrusão) os quais hidratam e gelatinizam as estruturas amorfas e cristalinas dos grãos de amido, aumentando a digestibilidade amilolitica das enzimas pancreáticas.

O nível de floculação e gelatinização do amido é determinado pelo tempo de exposição ao vapor, temperatura, umidade do grão, tamanho e distância entre os rolos e tipo de grão (MENEZES Jr, 1999; OWENS et al. 1997). 
Kienzle et al. (1997) avaliaram o efeito da morfologia do amido na digestão de cavalos fistulados no jejuno caudal e no ceco, alimentados com dietas contendo diferentes grãos e processamentos. Os autores relataram que existem barreiras para digestão do amido no trato gastrintestinal, como; estrutura das plantas, por exemplo, uma firme conexão entre os grânulos de amido em grãos de milho, tanto como; a própria estrutura dos grânulos de amido.

Kienzle (1994), verificou que a digestibilidade do amido tende a decrescer com o aumento do consumo por refeição e que o processo de moagem mecânica tanto como a laminação ou trituração não altera significativamente a digestibilidade de amido no intestino delgado, enquanto a trituração fina de grãos aumenta a digestibilidade. Da mesma forma, observou que a micronização e especialmente a expansão incrementa significativamente a digestibilidade do amido no intestino delgado de cavalos, atribuindo esses efeitos a maior ou menor destruição da estrutura botânica do amido durante o processamento.

Haelein; Smith; Yoon, (1966) comparando os coeficientes de digestibilidade do feno de alfafa na forma peletizada, farelada e achatada encontraram coeficientes de digestibilidade da fibra $15 \%$ menor na forma peletizada em relação às demais formas, contudo Manzano (1978) e Todd et al. (1995) não encontraram diferenças nos coeficientes de digestibilidade entre as formas de processamento do concentrado fornecido a eqüinos.

Meyer; Radicke; Kienzle (1993), trabalhando com diferentes formas de processamento de grãos de milho (inteiro, laminados, triturados, moídos e expandidos) oferecidos a eqüinos relataram que a digestibilidade pré-ileal do amido de milho foi significativamente maior do que o milho inteiro ou triturado 
possivelmente resultado do aumento da superfície de exposição às enzimas digestivas.

Estudos recentes feitos no Brasil e no exterior tem constatado a superioridade da floculação do milho sob a laminação a vapor na performance de vacas leiteiras (SANTOS et al. 1999; THEUER et al.; 1999 ; YU et al. 1997).

Quando comparada coma laminação a seco, a floculação reduziu o consumo de matéria seca sem diminuir o ganho de peso diário no desempenho de novilhos de corte, aumentando, portanto a eficiência alimentar (BARAJAS 1998; OWENS et al. 1997).

\subsection{Digestibilidade dos nutrientes}

Digestível é considerada a parte do alimento que não é eliminada com as fezes, correspondendo, não totalmente, á porção do alimento que ganha o meio interno através da parede do trato digestivo (MEYER, 1995).

Segundo Andriguetto (1999) vários fatores afetam a digestibilidade nos eqüinos, pois cada indivíduo, dentro da espécie, ingere, digere e absorve nutrientes de forma específica e usualmente diferente. Para Olsson (1955) além do fator individual, fatores como a composição química do alimento, a capacidade de alimentação, o tipo de trabalho, a granulometria do alimento, o conteúdo de água presente no alimento, a velocidade de trânsito da ingesta no trato digestivo e a quantidade de fibra presente na ração podem interferir na digestibilidade dos alimentos. Meyer (1995), cita que as alterações na arcada dentária, o parasitismo e 
mudanças comportamentais levando ao aumento do peristaltismo, podem interferir negativamente sobre a digestibilidade.

Haelein; Smith; Yoon, (1966) pesquisando as taxas de excreção fecal em eqüinos e jumentos relatam que as formas de tratamento a que são submetidos os alimentos alteram sua digestibilidade.

A digestibilidade aparente se refere á proporção do alimento ingerido, possível de ser digerida e absorvida no trato gastrintestinal, portanto, quanto maior a digestibilidade de uma ração maior será a quantidade de nutrientes fornecidos para os processos de mantença, crescimento, reprodução e trabalho (CARVALHO, 1992).

Para Fuller (1991) os coeficientes de digestibilidade aparentes têm sido aceitos por oferecerem valores próximos dos reais como medida da utilização de cada componente da dieta na alimentação animal. Nyberg (1993) cita que proteínas e lipídios sofrem ação do processo digestivo sendo em parte absorvidos e utilizados pelo organismo, entretanto em adição as frações de nutrientes não digeridas e eliminadas pelas fezes, existem também compostos formados pela ação da extensa flora gastrintestinal, sendo considerada como parte utilizada.

Muares possuem maior capacidade de digestão de FDA e FDN do que cavalos e pôneis, provavelmente pelo fato dos muares serem capazes de reterem mais partículas alimentares por longo tempo no aparelho digestivo em comparação a outros animais (CUDDERFORD et al., 1995).

Butler e Hintz apud CUNHA (1991) concluíram que a freqüência de alimentação não afetou os coeficientes de digestibilidade da MS, PB, FDN e FDA quando foi usada uma ração peletizada em dietas fornecidas a pôneis em 1,2 e 6 alimentações vezes ao dia, porém um mínimo de dois fornecimentos diário seria indicado para evitar problemas digestivos. 
Carvalho (1992) verificou a influencia da ordem de fornecimento de volumoso e concentrado na alimentação de eqüinos, por meio de um ensaio de digestibilidade, verificando que o fornecimento do volumoso antes do concentrado ou do volumoso misturado ao concentrado proporciona melhores coeficientes de digestibilidade.

Como a fibra bruta não é uma substância homogênea quanto maior os teores de lignina menor a digestibilidade de seus nutrientes devido ao fato desta não poder ser totalmente degradado pelos microrganismos e eventualmente revestir parcialmente os outros nutrientes de maneira a dificultar o acesso das enzimas próprias dos organismos ou das produzidas pelos microrganismos (MEYER 1995).

Geralmente, o declínio da digestibilidade dos nutrientes das plantas forrageiras, ocorre à medida que estas amadurecem, estando associado ao aumento dos teores de lignina assim estimativas da concentração de lignina na parede celular torna-se então essencial para determinação do valor nutritivo (FUKUSHIMA 1995).

Apesar da digestibilidade total do amido ser alta, variando de 87 a 100\%, os eqüinos possuem baixa atividade da enzima alfa-amilase pancreática, o que pode comprometer a digestibilidade pré-cecal de dietas com altas quantidades ou fontes morfologicamente complexas deste nutriente (KIENZLE, 1994; MEYER, 1995).

Meyer; Radicke; Kienzle (1993) trabalharam com pôneis fistulados no jejuno posterior e observaram que cinco fatores podem interferir diretamente na digestibilidade pré-ileal do amido: a fonte do grão, o tipo de processamento do grão, a quantidade consumida de amido, a fonte do volumoso e possíveis diferenças individuais entre os animais. Consumos excessivos de amido também podem interferir na digestibilidade, sobrecarregando a capacidade do Intestino delgado, assim como, consumo de dietas com altos teores de fibra, que aumentam a taxa de passagem, dificultando a ação enzimática. 
Massey et al. (1985) avaliaram a digestão aparente parcial e pré-cecal e pósileal do amido, em um concentrado comercial fornecido em duas, três ou quatro refeições em intervalos, respectivamente, de doze, oito e seis horas entre as refeições. Os autores não observaram diferenças nos coeficientes de digestibilidade aparente parcial pré-cecal e pós-ileal do amido, concluindo que dietas com alta proporção da relação concentrado/volumoso (70/30\%) podem ser fornecidas em apenas duas refeições por dia para atender as exigências de energia digestível para mantença.

Radicke; Kienzle; Meyer (1993) compararam a digestão pré-ileal do amido presente na aveia e no milho, verificando também suas conseqüências para o metabolismo cecal. Os autores utilizaram dois pôneis fistulados na porção final do jejuno e dois pôneis fistulados no ceco, comparando os possíveis efeitos de diferentes níveis de ingestão de amido (1,0-8,0;1,0-4,0 e 1,1-3,0 g/kg peso vivo/refeição) e mudança brusca na dieta total. Os parâmetros avaliados na digesta cecal foram a concentração de lactato, $\mathrm{pH}$ e ácidos graxos voláteis (AGV) e os autores concluíram que a baixa digestibilidade do amido até o final intestino delgado, implica em um alto fluxo deste componente para o interior do ceco e alto risco de acidose metabólica subclinicas.

\subsection{Métodos empregados para determinação de digestibilidade aparente dos nutrientes em eqüinos}

A estimativa de valores de digestibilidade é reconhecidamente um dos primeiros parâmetros do valor nutritivo do alimento. Os métodos mais empregados 
para determinação de digestibilidade dos nutrientes em eqüinos são, a coleta total, e os indicadores externos e internos.

O método de coleta total, também chamado de convencional ou padrão, consiste no controle total do alimento ingerido e na coleta total das excreções dos animais, sendo os coeficientes de digestibilidade aparente calculados a partir da analise química de cada fração (LLOYD 1978).

Sankhyan et al. (1999) descreveram a técnica da coleta total como a mais acurada para determinação de digestibilidade aparente em animais. Dentre os métodos de coleta total mais utilizados na determinação da digestibilidade dos nutrientes em eqüinos, destacam-se as baias com pisos e paredes impermeabilizadas, as bolsas coletoras e as gaiolas metabólicas Araújo (1999).

Van Der Noot; Fonnesbeck; Lydman (1965) desenvolveram bolsas coletoras para contornar as dificuldades próprias a coleta quantitativa das fezes. De acordo com Parkins; Snnowd; Adams, (1982), o emprego de bolsas coletoras implica na utilização de arreios apropriados, fazendo com que alguns animais não se adaptem perfeitamente ao sistema apresentando inconstância fisiológica.

As gaiolas metabólicas começaram a ser utilizadas para se diminuírem as dificuldades encontradas com a utilização das bolsas coletoras Stillions (1968). Knapka et al. (1967) utilizando gaiolas metabólicas em trabalhos com asininos, observaram mudanças no comportamento dos animais e por conseqüência alterações nos coeficientes de digestibilidade. Veiga et al (1974) utilizaram baias comuns de pisos e paredes impermeabilizadas sendo as fezes feitas inteiramente feitas no piso, esse método necessita de cuidados especiais para que haja coleta separada de urina e fezes evitando assim contaminações. 
Para Nascimento (2001), um dos inconvenientes da técnica de coleta total de fezes, consiste no fato de que durante o período experimental, os animais ficam confinados em condições desfavoráveis a manutenção da espécie, levando a irregularidades fisiológicas com influencia negativa sobre o processo digestivo. A técnica de coleta total de fezes ainda apresenta outros fatores negativos como o de restringir o número de animais experimentais à disponibilidade de infra-estrutura, além de exigir mão-de-obra previamente qualificada.

Alternativamente ao método da coleta direta, tem sido proposto o método dos indicadores, ou indireto, que é fundamentado no emprego de uma substância índice ou indicador que, ao ser ingerida na dieta, deve ser totalmente recuperada nas fezes (SILVA; CAMPOS; CONRAD, 1968).

Indicador é o termo utilizado para denominar material usado na estimativa qualitativa ou quantitativa de fenômenos fisiológicos ou nutricionais, portanto, é uma referência, um composto usado como monitor físico - químico de aspectos da digestão Owens; Hanson (1992). Indicadores possuem grande aplicação no estudo das taxas de passagem de líquidos e sólidos, de consumos voluntários, de produção fecal e de digestibilidade de alimentos em animais em pastejo ou confinados (TEIXEIRA, 1997).

O exame da concentração dos indicadores no alimento e nas fezes permite avaliar os coeficientes de digestibilidade aparente Aroeira (1997); Church (1988). Segundo Saliba (2002) a validade de um indicador pode ser observada baseada em métodos alternativos, tais como coleta total das fezes.

Para Kotb; Luckey, (1972) os indicadores fecais oferecerem várias aplicações nos estudos nutricionais, tais como estimar a quantidade de alimento ou nutriente consumido, determinar a digestibilidade total ou parcial dos alimentos, medir o tempo 
de passagem da digesta total ou em qualquer parte do trato gastrintestinal. Segundo os mesmos autores o uso de indicadores fecais apresentam também a vantagem de substituir a coleta total de fezes por amostras aleatórias, reduzindo os custos dos experimentos de animais de grande porte. Para Silva e Leão as características ideais para uma substancia ser utilizada como indicador fecal são: não devem ser digeridos e nem absorvidos; não possuir ação farmacológica no aparelho digestivo; Misturar-se de maneira uniforme a digesta; serem dosados analiticamente com rapidez e segurança e de preferência ser constituinte natural do alimento.

Araújo (1999), descreve os Indicadores em internos, de ocorrência natural nos alimentos, e externos, sendo estes últimos adicionados à ração ou administrados ao animal.

O óxido crômico $\left(\mathrm{Cr}_{2} \mathrm{O}_{3}\right)$ tem sido extensivamente utilizado como indicador externo para a avaliação da digestibilidade como atestam trabalhos realizados por Knapka et al. (1967); Cross (1977); Cuddeford et al. (1990); Oliveira et al. (1991); Hansen et al. (1992); Alvarenga (1996) e Almeida (1998).

Van Der Noot; Fonnesbeck; Lydman (1965) mediram o tempo de passagem do oxido crômico pelo trato gastrintestinal de cavalos adultos concluindo que 3 dias de coleta são suficientes para experimentos de digestão, porém sugerem 5 dias para reduzir as diferenças individuais dos animais. Para Nascimento (2001), a concentração de óxido crômico nas fezes alcança o equilíbrio em torno de seis dias após a administração das doses iniciais e sua taxa de recuperação, pode ser teoricamente considerada de $100 \%$.

Para Bremer Neto (2003) a determinação do óxido crômico pelo método espectrofotométrico da s-difenilcarbazida possui sensibilidade que permite poder ser 
determinado em teores de até $0,01 \%$ da dieta gerando economia relativa ao consumo do mesmo, além de possuir grande exatidão.

Esse indicador externo pode ser administrado via sonda naso gástrica, através de cápsulas ou através de papel filtro misturado concomitantemente ao concentrado, todavia as perdas na recuperação advindas da administração, Church (1988) e a excreção irregular em relação a digesta Cudderford, Hugges (1990) são problemas comuns nestes ensaios.

Os indicadores internos são substancias presentes na composição dos alimentos que dispensam cuidados com a administração e acompanham a digesta através do trato gastrintestinal. Segundo Araujo (1999), dentro da literatura existem poucas pesquisas com o uso de indicadores internos para estimar a digestibilidade dos nutrientes em eqüinos, sendo a que a lignina é um dos indicadores mais estudados, enquanto a cinza insolúvel em detergente ácido (CIDA) e a cinza insolúvel em ácido clorídrico (CIA) apresentam resultados promissores.

Resultado da cinza residual da determinação de fibra em detergente ácido, a Cinza Insolúvel em Detergente Ácido (CIDA) tem sido utilizada em ensaios de digestibilidade em eqüinos com resultados satisfatórios. Machado (1992) avaliou a digestibilidade aparente dos nutrientes de diferentes combinações de capim elefante (Pennisetum purpureum) com cana de açúcar (Saccharum officinarum) utilizando CIDA, outros indicadores e coleta total obtendo eficiência de recuperação média de $98,21 \%$ e coeficientes de digestibilidade semelhantes àqueles obtidos pela coleta total. Araújo (1999) utilizando ração contento feno de coast - cross e milho e de uma ração composta de feno de coast-cross e farelo de soja dado a eqüinos, obteve percentagem média de recuperação de 99,66\%e coeficientes de digestibilidade 
semelhantes aos encontrados pelo método de coleta total, concluindo que CIDA foi eficiente indicador interno para estimar a digestibilidade aparente dos nutrientes.

Para Almeida et al. (1997) as estimativas de digestibilidade pré-cecal com a utilização de óxido crômico e com a CIDA resultaram em valores mais semelhantes, contudo considerando-se os erros-padrão das médias (EPM) observaram que os valores obtidos com o óxido crômico são mais homogêneos, sugerindo novos estudos sobre o uso desse e de outros indicadores internos devem ser conduzidos com eqüinos.

Carvalho (1989) trabalhando com nível de CIDA próximo ou maior que $3 \%$ da ração, não encontraram diferenças na determinação da matéria seca, matéria orgânica, parede celular (FDA) e conteúdo celular (FDN) quando a CIDA foi comparada a coleta total, porém onde o nível de CIDA foi menor que $3 \%$ os resultados de digestibilidade foram subestimados devido à dificuldade de recuperação da mesma nas fezes.

A lignina é um polímero, que ocorre naturalmente na parede celular vegetal formado por três polímeros condensados, álcoois p-coumaril, coniferil e sinapil, que se interligam numa malha complexa, resistente a hidrolise ácida e alcalina e a vários complexos enzimáticos inclusive as enzimas microbianas e tissulares do trato gastrintestinal dos animais superiores (FUKUSHIMA, 2003).

Fonnesbeck (1969) trabalhando com eqüinos encontrou variações na digestibilidade da lignina em leguminosas de -15.60 a 4.8\%, e em gramíneas de 0 a 16.40\%. Almeida (1997), Machado (1992), Maurício (1993) e Miraglia et al. (1999) obtiveram coeficientes de digestibilidade aparente subestimado devido aos baixos índices de recuperação da lignina nas fezes concluindo que a mesma mostra-se ineficiente para avaliar a digestibilidade dos nutrientes em eqüinos. 
Revisando o uso da lignina como indicador Fahey e Jung (1983) verificaram que a lignina foi digerida em rações contendo $100 \%$ de forragem e até $90 \%$ de concentrado, podendo, por conseguinte, ser usada como indicador somente quando apresentar evidências de sua alta recuperação fecal sendo que restrições ao uso da lignina devem se fazer a digestibilidade desta substancia quando contida em plantas em seu estágio inicial de crescimento. Em gramíneas jovens e em espécies vegetais com baixas concentrações de lignina, o menor grau de polimerização pode proporcionar uma digestibilidade da ordem de 20 a 40\% (van SOEST, 1994). Para Muntifering (1982) as razões aventadas para explicar a baixa recuperação da lignina nas fezes seriam a diferenciação dos monômeros fenólicos da lignina original (digestão verdadeira) a digestão aparente resultante da formação de complexo solúvel lignina-carboidrato, o qual não é recuperado nas fezes, a destruição parcial da lignina fecal pelos reagentes usados nos métodos analíticos e as diferenças físico-químicas entre os alimentos e as fezes na natureza do material definido, como lignina.

Segundo Van Soest (1994) os métodos para analisar quantitativamente a lignina podem ser classificados em gravimétricos, métodos medidos por diferença, após a remoção da lignina e métodos obtidos por absorbância. Muntifering (1982) concluiu que a escolha do método analítico e a extensão da recuperação da lignina afetam a interpretação do fluxo da digesta não observando melhora da análise por espectrofotometria sobre os métodos gravimétricos.

Van Soest (1994) recomenda o da lignina como indicador em rações com alto conteúdo de lignina, especialmente acima de $5 \%$ da matéria seca, contudo Giger (1985) não encontrou associação entre o conteúdo de lignina e a digestibilidade aparente, e observou variação em até $50 \%$ nos resultados conforme as técnicas 
analíticas utilizadas, afirmando que o não conhecimento detalhado da estrutura da lignina torna difícil a especificidade de todos os métodos de sua determinação.

Fukushima et al. (1991) observaram que alfafa em estágio vegetativo mais jovem apresentava, cerca de $20 \%$ da fração lignina em detergente ácido insolúvel em solução de clorito de sódio, possivelmente cutina, assim dependendo do método analítico empregado determinado alimento rico em cutina podem ter seus valores de lignina superestimados. 


\section{MATERIAL E MÉTODOS}

Para esse experimento foram adotados os materiais e as metodologias descritas a seguir:

\subsection{Local}

O experimento foi realizado nas dependências da Chácara São João, localizada no município de Espírito Santo do Pinhal, estado de São Paulo.

Os animais permaneceram, durante o período experimental, em baias com área de doze metros quadrados com piso e cochos de alvenaria e sem cama.

Todas as análises laboratoriais foram efetuadas no Laboratório de Bromatologia do Departamento de Nutrição e Produção Animal da Faculdade de Medicina Veterinária e Zootecnia da Universidade de São Paulo (FMVZ -USP) localizado no município de Pirassununga, estado de São Paulo.

\subsection{Animais}

Foram utilizadas neste experimento quatro éguas adultas, clinicamente sadias e com peso médio de $450 \mathrm{~kg} \pm 51,15 \mathrm{~kg}$. Todos animais foram previamente imunizados contra tétano e raiva sendo também vermifugados e pulverizados contra 
ectoparasitos. Para minimizar o estresse provocado pelo confinamento os animais foram exercitados a passo diariamente, durante quinze minutos.

\subsection{Clima}

O clima na região, segundo classificação de Köppen, descrita por Oliveira e Prado (1984) é do tipo Cwa - temperado chuvoso, com inverno seco e verão quente e úmido.

\subsection{Alimentação e dieta}

Os eqüinos foram alimentados seguindo as recomendações estabelecidas no Equine Nutrient Requiriments, NRC (1989), para eqüinos em manutenção. Para determinação da digestibilidade aparente foi utilizada uma dieta, composta por partes iguais de volumoso do feno da gramínea Tifton 85 (Cynodon sp), e concentrado com formulação descrita na tabela 1, cuja única forma de variação foi o processamento do milho (extrusado, floculado, laminado e moído). Os valores médios da composição bromatológica dos ingredientes dos quatro suplementos concentrados (100\% da MS) estão expostos na tabela 2. 
- Ração 1: feno + concentrado a base milho triturado

- Ração 2: feno + concentrado a base de milho laminado

- Ração 3: feno + concentrado a base de milho floculado

- Ração 4: feno + concentrado a base de milho extrusado

Tabela 1 - Formulação do concentrado experimental (\%).

\begin{tabular}{cccccc}
\hline $\begin{array}{c}\text { Farelo de } \\
\text { Soja }\end{array}$ & $\begin{array}{c}\text { Farelo de } \\
\text { Trigo }\end{array}$ & Milho & $\begin{array}{c}\text { Sabugo de } \\
\text { milho }\end{array}$ & Calcáreo & Sal \\
\hline 12 & 26,50 & 47,50 & 10 & 3 & 1 \\
\hline
\end{tabular}

Tabela 2 - Valores médios da composição bromatológica dos ingredientes dos quatro suplementos concentrados ( $100 \%$ da MS)

\begin{tabular}{|c|c|c|c|c|c|c|c|c|c|c|c|}
\hline Ingrediente & MS & MO & MM & $\mathrm{EE}$ & FB & PB & $\mathrm{Ca}$ & $\mathbf{P}$ & FDN & FDA & Amido \\
\hline F. soja & 89,00 & 82,60 & 6,40 & & 6,90 & 49,5 & 0,40 & 0,70 & 18,90 & 11,40 & 1,60 \\
\hline F. trigo & 89,20 & 79,50 & 6,70 & & 9,30 & 18,80 & 0,10 & 0,90 & 43,10 & 17,40 & 12,80 \\
\hline Milho & 89,30 & 88,10 & 1,20 & 4,10 & 2,50 & 8,90 & 0,10 & 0,30 & 19,90 & 3,71 & 76,10 \\
\hline Sabugo & 90,00 & & & & 35,00 & 3,00 & 0,12 & 0,04 & & 40,00 & \\
\hline Calcita & & & & & & & 32,80 & & & & \\
\hline
\end{tabular}


A composição bromatológica do volumoso e do concentrado com as quatro formas de processamento do milho encontra-se descrita na tabela 3.

Tabela 3 - Composição bromatológica da fração concentrado com as quatro formas de processamento do milho (100\% da MS) e do feno da gramínea Tifton 85 (Cynodon sp)

\begin{tabular}{cccccccccccc}
\hline Trat. & MS & MO & MM & EE & FB & PB & FDN & FDA & LIG & CIDA & Amido \\
\hline TRIT & 85,39 & 78,63 & 6,76 & 1,72 & 7,73 & 17,34 & 1,96 & 0,63 & 27,72 & 11,23 & 40,11 \\
& & & & & & & & & & & \\
LAMI & 85,98 & 81,13 & 4,68 & 2,84 & 7,14 & 15,62 & 1,20 & 0,50 & 25,80 & 10,80 & 43,57 \\
& & & & & & & & & & & \\
FLOC & 86.32 & 95.58 & 4.42 & 1.49 & 7.69 & 15.71 & 26.64 & 12.36 & 4.97 & 0.04 & 42.42 \\
& & & & & & & & & & & \\
EXTR & 87.38 & 96.23 & 3.77 & 2.12 & 6.55 & 18.15 & 25.77 & 0.52 & 4.05 & 0.00 & 38.50 \\
& & & & & & & & & & & \\
FENO & 89.18 & 96.17 & 3.83 & 0.99 & 37.14 & 5.57 & 81.92 & 43.12 & 8.22 & 0.00 & 1.59 \\
\hline
\end{tabular}

O alimento foi fornecido em duas refeições, com intervalos constantes, as sete e dezessete horas, divididas em partes iguais entre os dois horários, adotandose o consumo diário individual de $2,0 \%$ do peso vivo (em matéria seca), sendo $50 \%$ de concentrado e $50 \%$ de volumoso. De acordo como sugerido por Carvalho (1992) concentrado e volumoso foram oferecidos ao mesmo tempo em comedouro separados sendo observado um tempo máximo de consumo para o concentrado de 45 minutos, a fim de padronizar os estudos de digestibilidade. 
Sal mineralizado e água estiveram à disposição dos animais a vontade

Antes do inicio do período experimental, com o propósito de facilitar o manejo alimentar, as dietas foram adaptadas para quantidades que permitissem o consumo total dos alimentos, não havendo necessidade de coleta das sobras.

Foram adicionadas as dietas dos animais dez gramas de óxido crômico misturado a pequena quantidade de concentrado, durante todos os dias de cada período experimental seguindo metodologia proposta por Nyberg (1993), sempre nos mesmos horários, as sete e dezessete horas.

Não foi observada, durante o período experimental qualquer alteração clínica nos animais que pudesse interferir tanto na aceitabilidade quando na coleta das amostras.

\subsection{Processamento físico do milho}

A trituração dos grãos de milho foi obtida em moinho de martelo sem peneira com granulometria aproximada de cinco $\mathrm{mm}$.

As condições de temperatura, tempo de permanência no sistema, umidade, pressão e tipo de rolo as quais foram submetidas às parcelas de grãos de milho (laminados, floculados e extrusados) que fizeram parte das dietas oferecidas aos animais utilizados neste experimento encontram-se descritas na tabela 4.

Amostras individuais das quatro formas de processamento foram retiradas sendo acondicionadas em sacos plásticos para posterior análise bromatológica. 
TABELA 4 - Condições de temperatura, permanência no sistema, umidade, pressão e tipo de rolo necessário para as diferentes formas de processamento de grãos de milho inteiro (laminados a vapor, floculado e extrusado) oferecidos aos animais.

\section{Laminação Floculação Extrusão}

Temperatura

( $\left.{ }^{\circ} \mathrm{C}\right)$

\section{Permanência no}

sistema

(min)

Umidade

( \%)

Pressão

$\left(\mathrm{Kgf} / \mathrm{cm}^{2}\right)$

Pressão

$\left(\right.$ Lbs/in $\left.^{2}\right)$

(Rolo)

Espessura rolo

(mm)
80

100

100

20

35

5

20

30

$25-30$

$3-4$

6,33

$42-54$

Estriado

Estriado /Liso

1,5

\subsection{Metodologia de Coleta e Processamento das Amostras}

O experimento constou de quatro períodos de onze dias cada, sendo oito primeiros dias de adaptação às dietas e três dias para coleta de fezes.

Amostras individuais das dietas fornecidas foram retiradas diariamente, durante os períodos de coletas sendo acondicionadas em sacos plásticos para posterior análise bromatológica. 
As fezes coletadas em um período de 24 horas foram pesadas, homogeneizadas manualmente e posteriormente retiradas uma taxa de $10 \%$ do total diário sendo acondicionadas em sacos plásticos, devidamente identificados e armazenado em freezer horizontal, com temperatura variando de 5o. a 10o.C negativos para posterior analise.

Após o término dos experimentos, as amostras foram descongeladas à temperatura ambiente, homogeneizadas, colocadas em duplicata em bandejas de alumínio sendo então pesadas e secas em estufas de ventilação forçada a $65^{\circ} \mathrm{C}$, por 72 horas, sendo posteriormente retiradas da estufa e novamente pesadas à temperatura ambiente (SILVA, 1990).

Depois da pré-secagem, as amostras foram moídas em moinho de lâminas com peneira de $1 \mathrm{~mm}^{2}$ e acondicionadas em sacos plásticos que permaneceram fechados até o momento de sua análise.

As análises para determinação da matéria seca (MS), proteína bruta (PB), fibra bruta (FB), fibra em detergente ácido (FDA), fibra em detergente neutro (FDN), extrato etéreo $(E E)$, matéria mineral $(M M)$, cálcio $(C a)$ e fósforo $(P)$ foram realizadas segundo metodologia descrita por SILVA (1990).

A quantificação do crômio foi feita de acordo com a metodologia descrita por Graner (1972). O método em questão fundamenta-se na reação entre o $\mathrm{Cr}_{2} \mathrm{O}_{3}$ e a sdifenilcarbazida em meio ácido, formando-se um produto de cor vermelho-violeta, com intensidade de cor proporcional ao teor de cromo na solução da amostra.

As determinações da concentração da lignina em detergente ácido (LDA) nas fezes e nos alimentos utilizados foram realizadas conforme metodologia descrita por Van Soest et al. (1991). O princípio do método consiste em o ácido sulfúrico a $72 \%$ digerir a celulose a partir da fibra em detergente ácido, obtendo como resíduo lignina 
e cinzas insolúveis. Por diferença de peso antes e após a queima em mufla, calculase o teor de lignina.

A Cinza Insolúvel em Detergente Ácido foi mensurada como resíduo proveniente da queima a $525^{\circ} \mathrm{C}$, da fibra em detergente ácido conforme descrito por Van Soest (1991).

\subsection{Cálculo dos coeficientes de digestibilidade aparente}

A determinação do coeficiente de digestibilidade aparente dos nutrientes pela técnica da coleta total de fezes foi realizada segundo a descrição de MIRAGLIA et al., (1999) através das seguintes formulas:

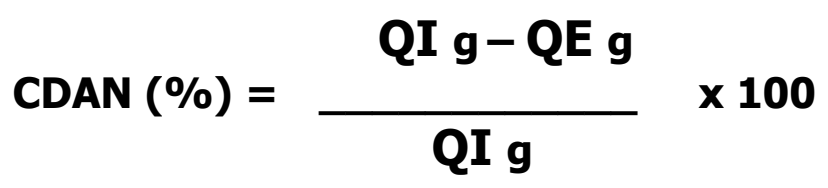

Onde:

CDAN (\%) é o coeficiente digestibilidade aparente dos nutrientes;

QI g é a quantidade ingerida de um nutriente em gramas;

QE g é a quantidade excretada do nutriente em gramas nas fezes. 
Os cálculos dos coeficientes de digestibilidade aparente dos nutrientes obtidos pela técnica de indicadores foram realizados segundo a descrição de Church (1988) através das seguintes formulas:

\section{CDAN $=100-100(A / B)$}

Onde:

CDAN é o coeficiente digestibilidade aparente dos nutrientes;

A é a concentração do indicador ingerido (\% da MS);

B é a é a concentração do indicador ingerido (\% da MS).

A eficiência de recuperação dos indicadores foi determinada pela formula:

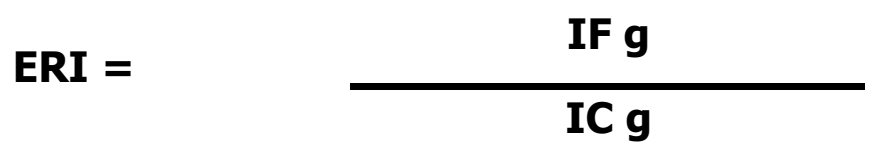

Onde:

ERI é a eficiência de recuperação do indicador;

IF g é a presença do indicador nas fezes em gramas (g);

IC g é a presença do indicador no alimento consumido em gramas 
Para análise estatística foram comparados os valores de digestibilidade da matéria orgânica obtidos pelo método de coleta total com os valores estimados por meio dos indicadores internos Lignina em Detergente Ácido (LDA), Cinza Insolúvel em Detergente Àcido (CIDA) e pelo indicador externo óxido crômico $\left(\mathrm{Cr}_{2} \mathrm{O}_{3}\right)$. A ponderação estatística utilizada segundo metodologia proposta por Jonker; Kohn; Erdman (1998) citados por Stein (2002). Neste experimento foram considerados os conceitos de viés como sendo a diferença entre a estimativa do CDMO pelo indicador e a estimativa de CDMO obtido pela coleta total.

Foi determinada Acúracia como sendo a capacidade de se direcionar a atenção para aquilo que se quer observar, sendo por definição acurado o indicador que possuir um viés médio próximo ao valor zero.

Precisão e a maior ou menor proximidade entre a observação ou a precisão que foi realizada( estimativa do indicador) e o fato que realmente aconteceu ( resultados obtidos pela coleta total), conseqüentemente quanto maior o desvio padrão observado para os vieses dos indicadores, maior a precisão.

Robustez como sendo a caracterização do indicador que é menos influenciada por fatores alheios tais como (peso, idade tratamento, consumo) para que o indicador se enquadre neste conceito, deve possuir em relação as retas de regressão do viés versus variáveis, pequenos coeficientes angulares e de determinação $\left(\mathrm{R}^{2}\right.$ ), grandes erros padrões e ainda inexistência de inclinação da reta indicada por altas probabilidades estatísticas.

As estimativas do modelo foram comparadas com os valores de viés (CDMO indicador - CDMO coleta total) do grupo de dados de cada indicador. As medias dos vieses e os respectivos desvios padrões foram calculados. Para avaliar a acurácia dos indicadores os vieses foram submetidos a analise de variância pelo teste não- 
paramétrico de Kruskall-Wallis. Para determinação da precisão foram utilizadas as variâncias comparadas pelo teste de Bartlett. A robustez da lignina foi obtida regredindo foi obtida regredindo o viés contra os próprios valores de CDMO estimados pelo indicador e contra a Variável FDA. Para isso utilizou-se o PROC GLM ( SAS , 1989). Para comparação das inclinações das retas foi usado o teste $T$ student. Os testes experimentais utilizados foram aplicados segundo Milliken e Johnson (1984) e a probabilidade considerada foi de $5 \%$.

$\sum$ (Coleta Total - Indicadores)

Acúracia

Número de observações 


\subsection{Delineamento experimental}

O delineamento utilizado foi em quadrado latino $4 \times 4$, com quatro tratamentos e quatro repetições. As variáveis foram analisadas segundo o modelo matemático:

$$
Y i j k=\mu+T k+P j+A i+e i j k
$$

Onde:

Yijk = coeficiente de digestibilidade da $\mathrm{MO}$ ou recuperação do indicador referente ao animal i, período j e tratamento k;

$\mu=$ média geral;

Tk = efeito do tratamento (Triturado, Laminado, Floculado, Extrusado);

$\mathrm{Pj}=$ efeito do período de coleta $(1,2,3,4)$;

$\mathrm{Ai}=$ efeito do animal $(1,2,3,4)$;

eijk = erro aleatório associado a cada observação. 
Os valores médios da recuperação dos indicadores e as médias dos coeficientes de digestibilidade da MO foram submetidos a contrastes ortogonais e comparados por testes de médias. As análises estatísticas foram realizadas pelo GLM do Statistical Analysis Systems (SAS, 1990). 


\section{RESULTADOS E DISCUSSÃO}

Segundo Forbes (1995), entre os fatores que afetam diretamente a digestibilidade de um alimento destaca-se, como de maior importância, o nível de consumo do animal, sendo que esta relação obedece a um padrão inversamente proporcional, ou seja, quanto menor o nível de consumo, maior a digestibilidade dos nutrientes.

Por outro lado alguns ensaios com eqüinos demonstram que o nível de consumo parece não afetar a digestibilidade dos nutrientes. Martin-Rosset; Doreu; Boulot (1990) estudaram a influência do nível de consumo na digestibilidade dos nutrientes de uma ração contento $85 \%$ de feno e $15 \%$ de concentrado em cavalos adultos de raças leves, verificando que o consumo não afeta a digestibilidade das forragens para eqüinos. Segundo os mesmos autores alimentação de mantença e $60 \%$ acima da mantença não afetaram os coeficientes da MS, MO, PB, FB e EB.

TODD et al. (1995) trabalhando com eqüinos adultos os quais foram alimentados com dietas compostas por feno de alfafa em cubos ao nível de mantença e 40\% acima da mantença também encontraram coeficientes de digestibilidade semelhantes para MS, MO, EB e PB.

Na tabela 5 estão os valores médios de peso vivo e de consumo dos animais durante o experimento. As éguas não apresentaram nenhuma alteração de consumo durante todo o transcorrer do experimento. 
TABELA 5 Media de peso vivo $(\mathrm{kg})$, consumo ( $\mathrm{kg} \mathrm{MS} / \mathrm{dia})$ e proporção de consumo de matéria seca por peso vivo de dietas compostas de feno da gramínea Tifton 85 (Cynodon sp) e do concentrado com as quatro formas de processamento do milho (100\% da MS).

\begin{tabular}{|l|c|c|c|c|}
\hline Animais & $\mathbf{1}$ & $\mathbf{2}$ & $\mathbf{3}$ & $\mathbf{4}$ \\
\hline PV (kg) & 406 & 492 & 412 & 502 \\
\hline CMS(kg/dia) & 7,62 & 8,09 & 8,30 & 8,31 \\
\hline CMS (\%PV) & 1,87 & 1,74 & 2,01 & 1,75 \\
\hline
\end{tabular}

As ingestões médias de matéria seca (MS) observada durante o período experimental foram semelhantes às recomendadas por Frape (1986) e Meyer (1995), e superior as recomendações de $1,68 \%$ peso vivo, apregoadas pelo NRC (1989) para eqüinos com o peso médio observado. Resultados semelhantes a estes também foram obtidos por Araújo (1999) que obteve valores entre 1,96 e 2,11\% PV utilizando dietas mistas para cavalos e avaliando os níveis de ingestão. 


\subsection{Digestibilidade Aparente Total da Matéria Orgânica e recuperação dos indicadores}

Os resultados da digestibilidade aparente da Matéria orgânica nas dietas compostas de feno da gramínea Tifton 85 (Cynodon sp) e do concentrado com as quatro formas de processamento do milho encontram-se descrito na tabela 6.

Tabela 6 - Coeficientes médios, erro padrão da média e média geral dos indicadores, da digestibilidade aparente da matéria orgânica (CDMO) obtidos através da coleta total (CT) e dos indicadores internos Cinza Insolúvel em Detergente Ácido (CIDA), Lignina (LIG) e do indicador externo Óxido Crômico $\left(\mathrm{Cr}_{2} \mathrm{O}_{3}\right)$ de dietas compostas de feno da gramínea Tifton 85 (Cynodon $s p$ ) e dos concentrados com as quatro formas de processamento do milho (\%).

\begin{tabular}{|c|c|c|c|c|}
\cline { 2 - 5 } \multicolumn{1}{c|}{} & CT & CIDA & LIG & $\mathrm{Cr}_{2} \mathrm{O}_{3}$ \\
\hline TRIT & $63,38 \pm 1,87$ & $72,28 \pm 4,58$ & $61,12 \pm 2,77$ & $51,25 \pm 0,82$ \\
\hline LAM & $66,86 \pm 2,35$ & $73,94 \pm 4,61$ & $53,10 \pm 3,06$ & $53,91 \pm 2,52$ \\
\hline FLOC & $65,69 \pm 0,66$ & $72,96 \pm 4,83$ & $57,23 \pm 1,12$ & $53,57 \pm 2,27$ \\
\hline EXTR & $62,73 \pm 0,95$ & $69,7 \pm 5,35$ & $63,29 \pm 1,13$ & $51,64 \pm 3,60$ \\
\hline $\begin{array}{c}\text { Média } \\
\text { geral ind. }\end{array}$ & 64,66 & 72,22 & 58,68 & 52,59 \\
C V (\%) & 3,00 & 2,51 & 7,65 & 2,55 \\
\hline
\end{tabular}


Os valores médios obtidos neste experimento para a digestibilidade aparente total da MO $(64,66 \%)$ pelo método da coleta total foram semelhantes aos obtidos nos trabalhos realizados por Gobesso (2001) e Almeida et al (1997), onde os valores médios da digestibilidade aparente total da $\mathrm{MO}$ com a coleta total, foram respectivamente de 68,1 e $64,33 \%$ e superiores aos $60,71 \%$ encontrados por Araújo (1999).

Os valores médios da digestibilidade da $\mathrm{MO}$ observados pelo uso dos indicadores, lignina, CIDA e $\mathrm{Cr}_{2} \mathrm{O}_{3}$, quando comparados com os obtidos através da coleta total foram significativamente diferentes $(P<0,05)$ para as quatro dietas.

Os coeficientes de digestibilidade dos nutrientes determinados por meio da lignina foram subestimados em relação aos demais indicadores e ao método de coleta total, possivelmente devido a sua baixa média de recuperação $(68,18 \%)$, resultados semelhantes aos encontrados por Araújo (1999).

Os valores da digestibilidade da MO obtidos com o indicador externo oxido crômico também foram significativamente diferentes dos obtidos com a coleta total discordando dos resultados obtidos por ALMEIDA et al. (1997), que trabalhando com digestão em eqüinos, descreveram o óxido crômico como o mais adequado indicador para ensaios de digestibilidade, em comparação a Fibra em Detergente Acida (FDA), lignina e Cinza Insolúvel em Detergente Acido (CIDA). Neste sentido Gobesso (2001) também obteve valores subestimados para digestibilidade aparente total da MO de eqüinos alimentados com dietas compostas de concentrado a base de milho e feno de gramínea. 


\subsection{Ponderação dos indicadores internos}

O Conteúdo de indicadores internos no feno da gramínea Tifton 85 (Cynodon sp) e nos concentrados contendo milho submetido a quatro processamentos diferentes (moído, laminado, floculado, extrusado), estão descritos na tabela 7.

TABELA 7 - Conteúdo de indicadores internos (\%) no feno da gramínea Tifton 85 (Cynodon sp) e nos concentrados contendo milho submetido a quatro processamentos diferentes (moído, laminado, floculado, extrusado).

\begin{tabular}{|c|c|c|}
\hline TRATAMENTO & CIDA & LIG \\
\hline FENO & 1,37 & 8,22 \\
\hline TRIT & 0,04 & 3,17 \\
\hline LAM & ND & 2,58 \\
\hline FLOC & ND & 4,97 \\
\hline EXTR & ND & 4,05 \\
\hline
\end{tabular}

O Conteúdo diário de indicadores, em porcentagem, nas dietas contendo feno da gramínea Tifton 85 (Cynodon sp) e concentrados contendo milho submetido a quatro processamentos diferente, triturado (TRIT), laminado (LAM), floculado (FLOC) e extrusado (EXTR) estão descritos na tabela 8. 
TABELA 8 - Conteúdo diário de indicadores internos em (\%), nas dietas contendo feno da gramínea Tifton 85 (Cynodon sp) e concentrados contendo milho submetido a quatro processamentos diferente, triturado (TRIT), laminado (LAM), floculado (FLOC) e extrusado (EXTR)

\begin{tabular}{|c|c|c|}
\hline Tratamento & CIDA & LIG \\
\hline TRIT & 1,41 & 11,39 \\
\hline LAM & 1.37 & 10,80 \\
\hline FLOC & 1.37 & 13,19 \\
\hline EXTR & 1.37 & 12,27 \\
\hline
\end{tabular}

Para efeito de ponderação dos indicadores foi utilizado o modelo proposto por Jonker; Kohn; Erdman (1998), denominando-se de viés a diferença da estimativa do CDMO pelo indicador e do CDMO alcançado pela coleta total. Estas estimativas estão descritas na tabela 9.

As médias e os coeficientes de variação referentes à eficiência de recuperação dos indicadores $\mathrm{Cr}_{2} \mathrm{O}_{3}$, CIDA e Lignina em porcentagem estão descritas na tabela 10. 
Tabela 9 - Valores de acúracia e precisão para os indicadores Cinza Insolúvel em Detergente Ácido (CIDA), Lignina (LIG) e Óxido Crômico $\left(\mathrm{Cr}_{2} \mathrm{O}_{3}\right)$.

\begin{tabular}{l|cc}
\hline \multicolumn{1}{c|}{ Técnica } & Acurácia $^{*}$ & Precisão** $^{*}$ \\
\hline Óxido Crômico & $12,07^{\mathrm{a}}$ & $4,14^{\mathrm{b}}$ \\
\hline Lignina & $5,98^{\mathrm{b}}$ & $8,57^{\mathrm{a}}$ \\
\hline CIDA & $-7,55^{\mathrm{c}}$ & $7,85^{\mathrm{a}}$ \\
\hline
\end{tabular}

* Médias comparadas pelo teste não-paramétrico de Kruskall-Wallis

** Variâncias comparadas pelo teste de Bartlett

Letras diferentes dentro de colunas diferem pelos métodos estatísticos utilizados a

$5 \%$ de significância

TABELA 10- Eficiência média de recuperação e os coeficientes de variação dos indicadores $\mathrm{Cr}_{2} \mathrm{O}_{3}$, CIDA e Lignina (\%) para animais alimentados com dietas compostas de partes iguais de feno da gramínea Tifton 85 (Cynodon sp) e concentrado contendo milho submetido a quatro processamentos diferentes (moído, laminado, floculado, extrusado).

\begin{tabular}{|c|c|c|}
\hline Indicador & Média & CV \\
\hline $\mathrm{Cr}_{2} \mathrm{O}_{3}$ & 73,22 & 14,21 \\
\hline CIDA & 111,65 & 13,21 \\
\hline LIG & 68,18 & 19,38 \\
\hline
\end{tabular}


As medidas de acúracia dos indicadores internos Lignina e CIDA e do indicador externo óxido crômico com relação à média dos viese, apresentaram diferenças entre si pelo teste não-paramétrico de Kruskall-Wallis.

Neste experimento foi observada maior acurácia para a metodologia utilizando a lignina, em comparação aos demais indicadores testados $(P<0,05)$, porém ainda apresentando média de viés distante do valor zero (coleta total). assim como diferente de zero

Os valores de eficiência de recuperação da lignina $(68,18 \%)$ encontrados neste experimento proporcionaram estimativas de coeficientes de digestibilidade aparente da matéria orgânica subestimados em relação aos outros indicadores estudados e ao método da coleta total. A Lignina tem sido freqüentemente considerada como indigerível e conseqüentemente utilizada como indicador, entretanto a literatura mostra problemas com a determinação da lignina e sua recuperação fecal. Baixos índices de recuperação da lignina em eqüinos também foram observados por Fonnesbeck (1968), Machado (1992), Mauricio (1993) Almeida (1997) e Miraglia (1999). Evidenciando esses dados Fahey \& Jung (1983) mostraram que a lignina é degradada ou modificada estruturalmente durante a passagem pelo trato gastrintestinal resultando em baixa recuperação fecal.

A perda de material durante a passagem pelos intestinos é um dos critérios de avaliação do indicador, sendo uma das razões pela qual a lignina, como indicador, deve ser usada com cuidado. Segundo Church (1988), as razões aventadas para explicar a baixa recuperação da lignina nas fezes são: a digestão aparente resultante da formação de complexo solúvel lignina - carboidrato, o qual não é recuperado nas fezes; a destruição parcial da lignina fecal durante análise 
bromatológicas; diferenças físicas e ou químicas entre os alimentos e fezes quanto à natureza do material empiricamente definido como lignina.

Van Soest (1994) verificou digestibilidade da ordem de 20 a $40 \%$ em gramíneas imaturas e forragens com baixo conteúdo de lignina, segundo o mesmo autor a lignina deverá ser usada como indicador em dietas com alto conteúdo de lignina, sobretudo acima de $5 \%$ na matéria seca, neste experimento o conteúdo de lignina encontrado na MS nas dietas contendo feno da gramínea Tifton 85 (Cynodon $\mathrm{sp}$ ) e concentrado contendo milho submetido a quatro processamentos diferentes triturado(TRIT), laminado(LAM), floculado (FLOC) e extrusado(EXTR) foi em média maior de $10 \%$ na MS , porem não contribuiu para melhor eficiência de recuperação da lignina nas fezes.

Giger (1985) não encontrou associação entre o conteúdo de lignina e a digestibilidade aparente, porém observou variação em até $50 \%$ nos resultados conforme as técnicas analíticas utilizadas. A análise do indicador realizada nesta pesquisa através do método de detergente ácido, pode ter sido uma das causas da baixa recuperação da lignina nas fezes. Na análise da lignina em ácido sulfúrico a $72 \%$ a cutina e produtos de Maillard são mensurados como lignina, sendo que alguma lignina verdadeira poderá ser destruída na análise, prejudicando assim a interpretação dos resultados. A espectofotometria de compostos fenólicos, como a lignina solubilizada com solução ácida de dioxano, pode possuir maior acúracia para detectar componentes solúveis da lignina, que podem ser destruídos ou não serem mensurados nos métodos gravimétricos como o utilizado neste experimento.

A média dos vieses do indicador interno CIDA mostrou-se significativamente diferente dos demais indicadores apresentando resultados negativos, caracterizando 
que este indicador superestimou o CDMO. Apesar da insignificante porcentagem de CIDA na fração concentrado das dietas contendo milho, submetido a quatro processamentos (moído, laminado, floculado, extrusado) a combinação com o feno da gramínea Tifton 85 (Cynodon sp) proporcionou elevação dos níveis médios de CIDA da dieta para $1,38 \%$ da MS. A concentração da CIDA presente nas dietas parece ser controversa. Segundo Oliveira et al. (1991), a CIDA mostrou-se confiável para estimar a digestibilidade, para um teor médio de $1,2 \%$ na MS da dieta. Para Carvalho (1992) teores de $1,9 \%$ de CIDA na MS da dieta total foi considerado satisfatório possibilitando a obtenção de valores médios de recuperação próximos de 100\%. Fontes et al. (1996) obtiveram bons resultados na estimativa da digestibilidade da matéria seca com o uso da CIDA, com, níveis inferiores a $3 \%$ de CIDA e em período de coleta de fezes.

Contrariamente ao que ocorreu neste experimento onde apesar dos teores de CIDA presente na dieta serem muito pequeno os resultados do CDMO foram superestimados, Sherrod; Summers; Albin (1978) apregoam que níveis de CIDA próximos ou menores de $3 \%$ da dieta total podem comprometer os resultados subestimando os coeficientes de digestibilidade devido à baixa eficiência de recuperação do indicador.

Valores elevados de recuperação fecal da CIDA também foram encontrados por Zeoula; Branco; Salina (1994), que trabalhando com ovinos alimentados com rações com $1,5 \%$ de CIDA na MS, em consumo voluntário e consumo restrito, obtiveram valores de recuperação fecal de 140,8 e $114,2 \%$, respectivamente, concluindo que estes resultados propiciaram uma superestimativa dos coeficientes de digestibilidade, em comparação ao método de coleta total de fezes. 
O alto coeficiente de variação encontrado para esse indicador talvez possa ser atribuído ao fato deste experimento ter sido conduzido em baias de alvenaria possibilitando assim a contaminação dos alimentos e das fezes por agentes que poderiam interferir na eficiência de recuperação deste indicador. Outra hipótese para os valores superestimados de recuperação nas fezes e do CDMO, poderia ser o fato de que durante todo o período de coleta sal mineral esteve presente a vontade o que pode ter tido influencia nos resultados, seja por contaminação do piso ou por interferir sobre o delicado equilíbrio mineral da espécie eqüina. Lewis (2000) cita que dieteticamente deve-se considerar os minerais como um grupo e não individualmente, e que embora os elementos minerais constituam uma pequena fração do peso corporal e da quantidade de nutrientes exigidos na dieta, no entanto o fornecimento de um nutriente mineral acima do necessário, a quantidade absorvida e ou excretada pela urina e pelas fezes também poderá aumentar. Além desses fatores segundo Zeola (2000) cita que o método analítico da CIDA mais trabalhoso pode aumentar a probabilidade de erro na quantificação deste indicador.

A media dos vieses do Óxido Crômico também se mostrou significativamente diferente dos demais indicadores e também diferentes de zero com valores algébricos positivos caracterizando - se assim que esse indicador subestimou os coeficientes de CDMO. Almeida et al. (1997), sugeriu que o óxido crômico seria um bom indicador para ser utilizado neste tipo de experimentação, as taxas de recuperação de óxido crômico encontradas neste ensaio foram menores que as obtidas por Vander Noot et al. (1967) de $97 \%$ e as obtidas por Robinson e Slade (1974) e Haenlein et al., (1966) ao redor de 100\%, mas semelhantes aos encontrados por Alvarenga et al. (1997) e Gobesso (2001) respectivamente de . Maurício (1993) comparando os valores de digestibilidade de uma ração composta 
por partes iguais de concentrado e volumoso também obteve dados de digestibilidade subestimados devido à baixa recuperação deste indicador nas fezes.

O indicador externo Óxido Crômico já foi testado em experimentações administrado por via sonda nasogástrica, através de cápsulas, conjuntamente com pequena parcela de concentrado ou até mesmo ser adicionado durante o processo de fabricação do concentrado comercial, com resultados diferentes nas taxas de recuperação Patterson (2001). Neste trabalho o indicador foi previamente pesado em doses individuais, embrulhado em papel comum e administrado em junto a fração concentrado da dieta, podendo este procedimento ter influenciado negativamente a taxa de recuperação, uma vez que, uma parcela deste indicador ficou aderida ao papel, e outra, aderida ao cocho de alvenaria . Church (1988) e Cudderford (1990) enfatizam que as perdas advindas da administração e a excreção irregular em relação à dieta são problemas comuns em ensaios de digestibilidade utilizando esse indicador.

Para avaliação da precisão comparou-se os desvios padrões dos vieses dos indicadores 2 a 2. Foram mostradas diferenças significativas entre o desvio padrão dos vieses dos indicadores CIDA e Lignina do indicador oxido crômico. Considerando ser mais preciso o indicador quando menor o desvio padrão dos vieses obtidos por ele em relação à coleta total, o indicador óxido crômico foi constatado ser o mais preciso em relação aos demais indicadores estudados $(P<0,05)$ 
A figura 1 ilustra a avaliação da robustez da acurácia do indicador lignina em função da FDA de lignina.

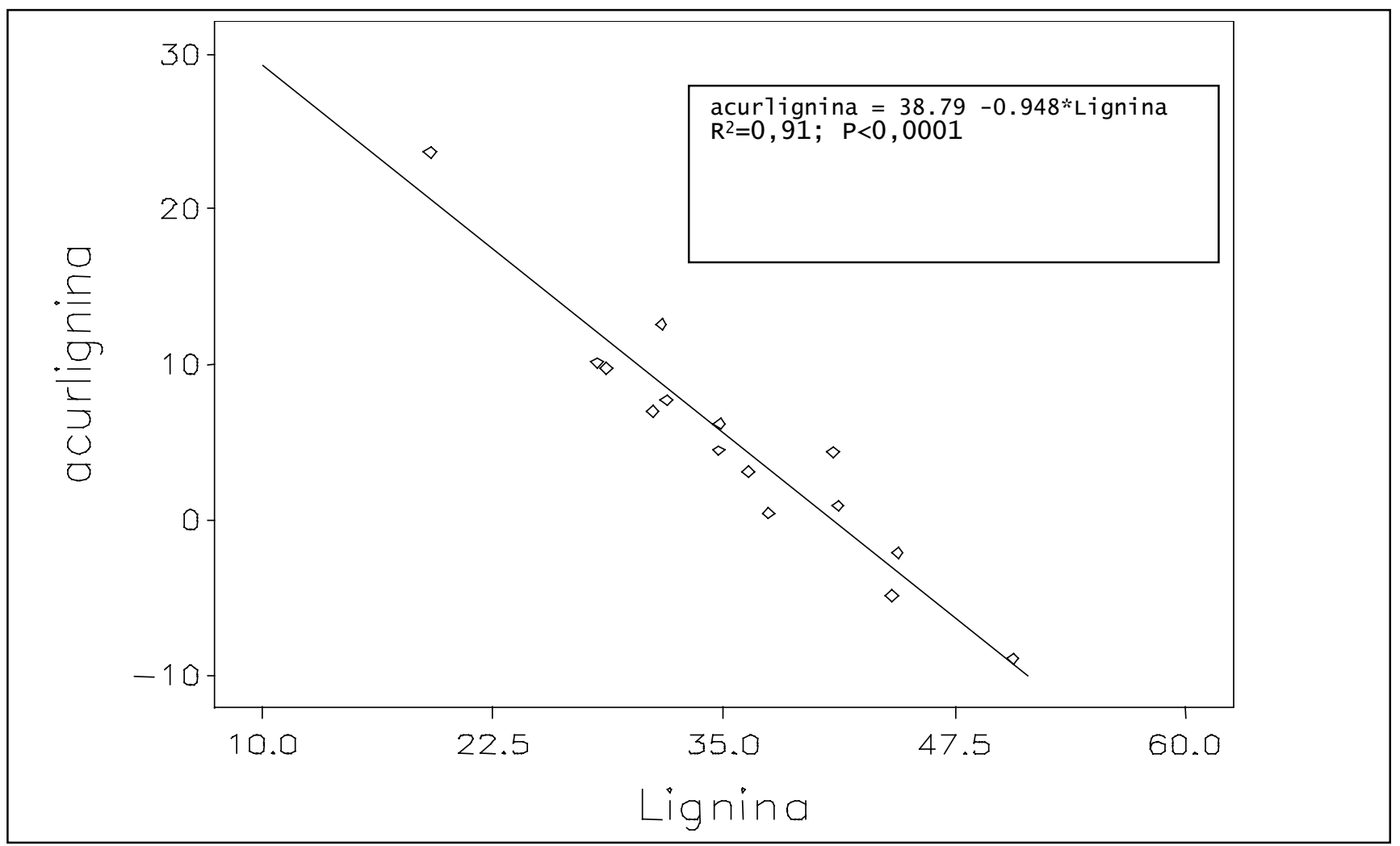


Os resultados obtidos com a robustez da acurácia de lignina em função da FDA ficam evidenciados em função das probabilidades estatísticas observadas quando se regrediu os vieses destes indicadores contra essa variável. O resultado significativo encontrado na baixa probabilidade indica a existência de inclinação na reta (alto coeficiente angular), deslocando - se assim em função da variável. Segundo a análise efetuada o indicador lignina sofre influência da variável FDA. O coeficiente de determinação $\left(R^{2}\right)$ alto de 0.91 demonstra a interferência da variável na estimativa do indicador, pois quanto mais alto o $\mathrm{R}^{2}$ maior a relação entre o viés e a variável , portanto maior a interferência da variável na estimativa.

O aumento na ingestão da variável lignina, poderá afetar a digestibilidade de compostos fibrosos através da elevação da taxa de passagem da digesta podendo segundo Oliveira (1995) deste modo a digestão incompleta digestão poderia subestimaras quantidades de FDA, afetando assim a estimativa de digestibilidade através desse indicador. 


\section{CONCLUSÕES}

Com base nas condições em que este trabalho foi desenvolvido, e segundo o modelo de avaliação efetuado, os indicadores internos lignina e Cinza Insolúvel em Detergente Ácido e o indicador externo Óxido Crômico, mostraram-se inadequados para estimar a digestibilidade aparente da matéria orgânica das dietas.

Novos trabalhos, com eqüinos avaliando as diferentes formas de fornecimento do indicador externo oxido crômico e composição das dietas e metabolismo mineral e o efeito sobre os indicadores internos lignina e Cinza Insolúvel em Detergente Ácido, são necessários para melhor avaliar o uso destes indicadores. 


\section{REFERÊNCIAS}

ALMEIDA, F.Q. ; VALADARES FILHO, S. C. ; LEÃO M.I. ; SILVA, J.F.C. ; CECON, P. R. ; LINHARES, R. S. Digestão pré-cecal em eqüinos: 2-Estimativa do fluxo de digesta ileal com indicadores externo e internos. In: XXXIV Reunião da SBZ, Juiz de Fora, 34 ; 1997. Anais. Juiz de Fora: SBZ, 1997.

ALVARENGA, R. C. Fluxo de matéria seca ileal, metodologias de coleta de digesta e digestibilidade aparente total e parcial em eqüinos. Viçosa: UFV, 59p.Dissertação (Mestrado em Nutrição de Monogástricos) - Universidade Federal de Viçosa. Viçosa, 1997.

ANDRIGUETTO, J.M. ; PERLY, L. ; MINARDI, I. Nutrição animal. 6 ed. São Paulo: Nobel, 1999.

ARAUJO K.V. Métodos para determinação da digestibilidade aparente dos nutrientes em eqüinos.Lavras: UFLA, 1999, 151p.(tese-doutorado em Zootecnia).

ARNOLD, F.F.; POTTER, G.D. ; KREIDER, J.L. Carbohydrate digestion in the small and large intestine of the equine, In: Equine Nutrition and Physiology Symposium, 8, Kentuky, 1983. Proceedings eighth.... Kentuky, 1983. P. 367.

AROEIRA, L.J.M. Estimativas de consumo de gramíneas tropicais. In Simpóso Internacional de digestibilidade em ruminantes, Lavras, MG, Anais...: UFL, Lavras, p127-163. 1997.

ASSOCIATION OF OFFICIAL ANALYTICAL CHEMIST - AOAC 1980. Official methods of the analysis.13.ed.Washington, DC. 1018p

BREMER NETO, H. ; GRANER, C.A.F. ; PEZZATO, L.E. Reduction in chromium (III) oxide level as an external marker. R. Bras. Zootec., vol.32, no.2, p. 249-255, 2003.

CARVALHO, F.F.R. de Efeitos de diferentes níveis de proteína bruta para cabras em lactação e uso de indicadores internos para estimar a digestibilidade dos nutrientes. Viçosa: UFV, 1989, 72p. (tese de mestrado em Zootecnia).

CARVALHO, M.A.G.de.Digestibilidade aparente em eqüinos submetidos a três condutas de arraçoamento. Belo Horizonte: UFMG,1992, 34p.(Tese-mestrado em Zootecnia).

CHURCH, D.C. Basic animal nutrition and feeding. New York: Wiley, 1988. 472 p. 
$\mathrm{CHURCH}, \mathrm{D} . \mathrm{E}$. The ruminant animal digestive physiology and nutrition. New Jersey, Prentice Hall, 563p; 1988.

COELHO DA SILVA, J.F. ; LEÃO, M.I. Fundamentos de nutrição dos ruminantes.Piracicaba: Livroceres Ltda, 1979, 380p.

CORTADA, C.N. M. ; VELLOSO, L. Uso da cinza insolúvel em ácido como indicador natural para a determinação da digestibilidade em bovinos. Revista da Faculdade de Medicina veterinária e Zootecnia da Universidade de São Paulo. São Paulo, v.24, n1 p.65-70.1987

CROSS, D. L. ; BOLING, J. A. ; BRADLEY, N. W. Chromic oxide and crude protein excretion in the bovine as influenced by water restriction. Journal Anim. Sci., 36(5):982-985, 1973.

CUDDERFORD, D. ; PEARSON, R.A., ARCHIBALD, R.F. Digestibility and gastrointestinal transit time of diets containining different proportions of alfalfa and oats given to thoroughbreds, Shetland ponies, Highland ponies and Donkeys. Animal Science v.61, p. 407-417, 1995.

CUDDERFORD, D. ; HUGHES D, A. Comparison between chromium-mordanted hay and acid-insoluble ash to determine apparent digestibility of a chaffed, mollassed hay/ straw mixture. Equine Vet. Journal.22, 122-125, 1990

CUNHA, T. J. Horse feeding and nutrition. Gainesville: Academic Press, 2ed. 1991, 445 p.

CYMBALUK, N. F. Comparison of forage digestion by cattle and horses. Canadian Journal of Animal Science. v.70, p.601-610, 1990.

DOS SANTOS, G.T., PETIT H.V. Prediction of total fecal output in sheep fed silage using the Captec chrome controlled-release capsule. Small Ruminant Research, v.20, p.223. 1996

FAHEY, G. C. ; JUNG, H. G. Lignin as a marker in digestion studies: a review. Journal Animal Science, 57 (1): 220-225. 1983

FERRET, A. ; PLAIXATS, J. ; CAJA, G. Using markers to estimate dry matter digestibility, faecal output and dry matter intake in dairy ewes fed Italian ryegrass or alfalfa hay. Small Ruminant Research. V.33, 3, p145-159, 1999.

FORBES, J. M. Voluntary food intake and diet selection in farm animals. Wallingford:I. 532p. 1995.

FRAPE, D. L. Dietary requirements and athletic performance of horses. Equine Veterinary Journal, v.20, n.3, p.163-172, 1988.

FUKUSHIMA, R. S. ; HATFIELD R. D. Composição fenólica de ligninas dioxano determinadas pela reação oxidativa com o nitrobenzeno. Pesq.agropec.bras., Brasília, v38, n.3, p.373-378, 2003. 
FULLER, M.F. In vitro digestion for pigs and poultry Wallingford: Redwood Press, 209p. 1991.

GOBESSO, A.A.O. Digestão pré-cecal e total de nutrientes utilizando diferentes dietas para equinos. Jaboticabal (Tese doutorado em Zootecnia). Faculdade de Ciências Agrárias e Veterinárias, 89p, 2001.

GRANER, C.A.F. Determinação do crômio pelo método da s-difenilcarbzida. Botucatu (Tese doutorado em ciências). Faculdade de Ciências Médicas e Biológicas, 112p., 1972.

HAELEIN, G. F. W.; SMITH, R. C.; YOON. Y.M. Determine of the fecal excretion rate of horses with chromic oxide, and cerium-144 as digestibility indicators in burros. The Journal of Nutrition, Philadelphia, v.92, n.1, p. 79-85, 1996.

HINTZ, H. F. Digestion in ponies and horses. Equine Practice v.12, p.5-6, 1990.

JONKER, J.S.; KOHN, R.A.; ERDMAN, R.A. Using milk urea nitrogen to predict nitrogen excretion and utilizations efficiency in lactating dairy cows. J.Dairy Sci., v. 81, n10, p. 2681-2692, 1998.

KERN, D. L. ;SLYTER, E. C. ; LEEFEL, J. M. ; ÖLTJEN R. R. Microbial and chemical characteristics of intestinal ingesta. Journal Animal Science, 38, 559-564,1974.

KIENZLE, E. Small intestinal digestion of starch in the horse. R. Méd. Vét., 145 (3): 199-204, mar. 1994b.

KNAPKA, J. J. ; BARTH, K. M. ; BROWN D. G. et al. Evaluation of polyethylene, chromic oxide, and cerium-144 as digestibility indicators in burros. The Journal of Nutrition, Philadelphia, v.92, n.1, p.79-85, 1967.

KOHNKE, J. R. Feeding and Nutrition. The making of a Champion. Birubi Pacific Copyright. Rouse Hill, p. 197, 1992

KOLLER, B. L. Comparative cell wall and dry matter digestion in the cecum of the pony and rumen of the cow using in vitro and nylon bag techniques. Journal Animal Science, 47 (1) : 209-215,1978.

KOTB, A. R. ; LUCKEY, T. D. Markers in nutrition. Nutrition Abstracts and Reviews .V.42, n3, p.814-845, jul.1972.

LLOYD, L.E. Fundamentos de Nutriçion. Zaragoza: Editorial Acribia,1978.464p.

MACHADO, H.M. Efeitos de diferentes combinações de capim elefante (Pennisetum purpureum, Schum): cana-de-açúcar (Saccharum officinarum, L.) sobre a digestibilidade em eqüinos, utilizando diferentes metodologias de determinação.Viçosa: UF, 1992, 71p. (Tese-mestrado em Zootecnia) 
MANZANO, A. ; CARVALHO, R.T.L. Digestibilidade aparente de uma ração peletizada e do arraçoamento tradicional em eqüinos.Pesquisa Agropecuária Brasileira. Brasília, v.13, n.4, p.92-99.1978.

MARTIN-ROSSET, W. ; DOREU, M. ; BOULOT, S. et al. Influence of level of feeding and physiological state on diet digestibility in light and heavy breed. Livestock Production Science. Amsterdam, v.25, p.257-264, 1990.

MASSEY, K.J. ; POTTER, G.D. Prececal, postileal and total tract starch digestion in ponies fed at varying intervals, In Equine Nutrition and Phisiology Symposium, 9, Michigan, 1985. Proceedings ninth .... Michigan, 1985.

MAURICIO R.M. Determinação da digestibilidade aparente em eqüídeos através do oxido crômico, da lignina e da coleta total de fezes. Belo Horizonte: UFMG-EV, 1993, 62p.( Tese - mestrado em Zootecnia).

MENEZES JR., M.P. Efeito do processamento do grão de milho e sua substituição parcial por polpa de citros peletizada sobre o desempenho, digestibilidade de nutrientes e parâmetros sanguíneos de vacas de leite. Piracicaba, 1999. 97p. Dissertação (Mestrado) Escola Superior de Agricultura "Luiz de Queiroz", Universidade de São Paulo.

MERCHEN, N.R. Digestion, absorption and excretion in ruminantes In: $\mathrm{CHURCH}$, D.C. (Ed.) The ruminant animal digestive physiology and nutrition. 4.ed. Carvallis: O\&B Books, p.172-201. 1993

MEYER, H.; RADICKE, S. \& KIENZLE, E. Investigation on preileal digestion of oats, corn and barley starch in relation to grain processing. In: Equine Nutrition and Physiology Symposium, 13, Gainesville, 1993. Proceedings thirteenth... P. 92,Gainesville, 1993.

MEYER, H. Alimentação de Cavalos.São Paulo: Livraria Varela Ltda. 303p.,1995.

MILLIKEN, G. A.; JOHNSON, D.E. Analysis of messy data, volume I, designed experiments. Belmont, CA, Lifetime Learning Publications, 1984.

MIRAGLIA, N. ; BERGERO, D. ; BASSANO, B. ; TARANTOLA, M., Studies of apparent digestibility in horses and the use of internal markers. Livestock Production Science, v.60, p.21-25, 1999.

MUNTIFERING, R.B. Evaluating of various lignin assays for determing ruminal digestion of roughages by lambs. Journal Animal Science, 55 (2): 432-438,1982.

NATIONAL RESEACH COUNCIL (NRC) - NATIONAL ACADEMY PRESS. Nutrients requirements of horses. 5 ed. Washington D.C., 1989. 100p

NYBERG, M.A. Flow rate through the small intestine of the equine determined with soluble and insoluble indicators given in a pulse and steady -state dose (Thesis Master of Science in animal Science). Texas A\&M University, 70p. 1993. 
OLIVEIRA, J. B .; PRADO, W. Levantamento pedológico do estado de São Paulo. São Carlos: Boletim técnico IAC, 1984

OLIVEIRA, R.F.M., FONTES, C.A.A., SILVA, J.F.C. et al. Estudo da recuperação fecal de $\mathrm{Cr} 2 \mathrm{O} 3$ e dos indicadores internos $\mathrm{CIA}$, CIDA e lignina em períodos de coleta de dois a sete dias, em bovinos. Revista Soc. Bras. Zootecnia, 20(5):522531,1991 .

OLSSON, N.; RUUDVERE, A. The nutrition of the horse. Nutrition Abstracts and Reviews, London, v.25, n.1, p.1-18, jan.1955.

OWENS F.N.; SECRIST D.S.; HILL W.J.; GILL D.R. The effect of grain source and grain processing on performance of feedlot cattle: A review. In: Journal Of Animal Science, 75: (3), p. 868-879, Mar. 1997.

PARKINS, J.J.; SNNOWD, H.; ADAMS, S. the apparent digestion of " complete diets" cubes given to thoroughbred horses and the use of chromic oxide as an internal fecal marker. British Vet Journal. v.138, p.350-355, 1982.

PATTERSON D.P.; COOPER S..R.; FREEMAN D.W.; TEETER R.G. Estimation of Fecal Output and Dry Matter Digestibility Using Various Chromic Oxide Marker Methods in the Horse. Disponível em: www. ansi. okstate. Edu /research /2001rr /33 133.htm

PIAGGIO, L.M.; PRATES, E.R.; PIRES, F.F. et al. Avaliação das cinzas insolúveis em ácido, fibra em detergente ácido indigestível e lignina em detergente ácido indigestível como indicadores internos da digestibilidade. Revista da Sociedade Brasileira de Zootecnia, v.20, n.3, p.306-312, 1991.

RADICKE, S.; KIENZLE, E., MEYER, H. Pre ileal apparent digestibility of oats and corn starch and consequences for cecal metabolism. In 13Th Equine Nutrition and Physiology Symposium, Calgary, 43p, 1991.

RALSTON, S.R. Feeding Behavior, Veterinary Clinics of North America: Equine Pratice-Vol.2 n3, 1986.

SALIBA E.O.S. ; RODRIGUES N.M. ; GONÇALVES L.C. ;MORAIS S.A.L. , Lignina isolada da palha de milho utilizada com indicador em ensaios de digestibilidade. Estudo comparativo. Arq. Bras. Med. Vet. Zootec. v.54 n.1 Belo Horizonte 2002

SANKHYAN, S.K. ; SHINDE, A.K. ;BHATTA, R. ;KARIM, S.A. Comparison of diet and faecal collection methods for assessment of seasonal variation in dry matter intake by sheep maintained on a Cenchrus ciliaris pasture. Animal feed Science and Technology, v82, p.261-269, 1999.

SHERROD, L.B.; SUMMERS, C.B.; ALBIN, R.C. et al. ADF insoluble ash, $\mathrm{HCl}$ insoluble ash and lignin as indicators for determining ruminant digestibility. Proceedings Western Section American Society of Animal Science, v.29, n.5, p.236-242, 1978. 
SILVA, D.J. Análise de alimentos (métodos químicos e biológicos). Viçosa: UFV, 1665p. 1990.

SILVA, J.F.C. ;CAMPOS, J. ;CONRAD J.H. Uso do oxido crômico na determinação da digestibilidade. Experientiae, v8, p.1-23, 1968.

SNEDECOR, G.W. ; COCHRAN, W.G. Statistical methods. 7.ed. Ames: lowa State University, 507p.,1980.

STATISTICAL ANALYSIS SISTEMS INSTITUTE. SAS/STAT® users guide : v 6.5 ed. Cary, NC: SAS institute INC., 1989. v2, 846p.

STEIN, R.B.B. Avaliação de métodos para determinação da digestibilidade aparente utilizando farelo de vagem de algaroba( Prosopis juliflora(Swartz) D.C.) em equinos. Pirassununga (dissertação de mestrado em Zootecnia). Faculdade de Zootecnia e Engenharia de Alimentos. 69p, 2002.

STILLIONS, M.C.; NELSON, N.E. Metabolism stall for male equine. Journal Animal Science. 27 (1): 68-72, 1968.

SUTTON, E.I. ; BOWLAND, J.P. ; McCARTHY, J.F. Studies with horses comparing $4 \mathrm{~N}-\mathrm{HCl}$ insoluble ash as an index material with total fecal collection in the determination of apparent digestibility. Can. Journal of Animal Sci, Ottawa, v.57, p.543-549, set.1977.

TISSERANT, J.L. A Alimentação prática do cavalo. São Paulo: Andrei. 83p.,1983.

TODD, K.L. ; SAUER, W.C. ;CHRISTOPHERSON, R.J. et al. The effect of level of feed intake on nutrient and energy digestibility and rate of feed passage in horses. Journal Animal Phys.and Animal Nutrition. Berlin v.73, p.140-148, 1995.

UDEN, P. ; van SOEST, P.J. Comparative digestion of timothy (Phleum pratense) fibre by ruminants, equine and rabbits. British Journal of Nutrition. Cambridge, v.47, p.276-272, mar.1982.

UDEN, P. ;COLUCCI, P.E. ; VAN SOEST P.J. Investigation of chromium, cerum and cobalt as markers in digesta. Rate of passage studies. Journal Sci.Agric.31: 625632, 1980.

VAN DER NOOT, G.W.; GILBREATH, E.B. Comparative digestibility of components of forages by geldings and steers. Journal of Animal Science.Champaign,v.31, n.2, p.351-355.ago.1970

VAN DER NOOT, G.W.; FONNESBECK, P.V. ; LYDMAN, R.K. Equine Metabolism stall and collection harness. Journal of Animal Science. Champaign, v.24, n.3, p.691-698.1965.

VAN SOEST, P.J. Nutritional ecology of the ruminant. Ithaca: Comstock Publishing Associates/ Cornell University Press, 1994. 476p. 
VAN SOEST, P.J.; ROBERTSON, J.B.; LEWIS, B.A. Symposium: Carbohydrate metodoloy, metabolism, and nutritional implications in dairy cattle. Methods for dietary fiber, neutral detergent fiber, and non starch polysaccharides in relation to animal nutrition. J. Dairy Sci., v.74, p.3583-97. 1991.

VEIGA, J.S.M.; ANDREASI, F. ; PRADA, F. ; MENDONÇA JR. C. X. Digestibilidade aparente da matéria seca em eqüinos " $1 / 2$ sangue bretão $1 / 2$ sangue inglês" Revista da Faculdade de Medicina Veterinária e Zootecnia da Universidade de São Paulo, São Paulo, V.11, p.7-20, 1974.

WARNER, A. C. Rate of passage digesta through the gut of mammals and birds. Nutrition Abstracts and Reviews (series B), London, v.51, n.12, p789-820, 1981.

WOLTER, R. Alimentação del Caballo. Zaragosa: Acribia, 172p. 1975.

ZEOULA, L. M.; PRADO, I. N. ; Moura P. H et al. Fecal Recuperation of Internal Markers in Assay with Ruminants. R. Bras. Zootec, vol.31, no.4, p.1865-1874, 2002

ZEOULA, L.M.; BRANCO, A.F.; SALINA, L.J. Avaliação de indicadores em estudo de digestibilidade de alimentos para ruminantes. Revista Unimar, v.22, n.3, p.165-174, 1994. 